U.S. Department of Homeland Security

Science \& Technology Directorate Test,

Evaluation, and Standards Division Standards Office

under U.S. Department of Energy Contract DE-AC05-76RL01830

Emergency Preparedness and Response (EP\&R)

Standards Development Project

\title{
Technical Review of Law Enforcement Standards and Guides Relative to Incident Management
}

\author{
RD Stenner JR Stanton \\ R Salter D Fisher
}

March 2009

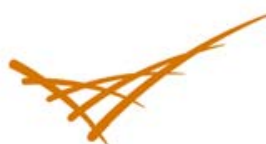

Pacific Northwest

NATIONAL LABORATORY 


\title{
DISCLAIMER
}

This report was prepared as an account of work sponsored by an agency of the United States Government. Neither the United States Government nor any agency thereof, nor Battelle Memorial Institute, nor any of their employees, makes any warranty, express or implied, or assumes any legal liability or responsibility for the accuracy, completeness, or usefulness of any information, apparatus, product, or process disclosed, or represents that its use would not infringe privately owned rights. Reference herein to any specific commercial product, process, or service by trade name, trademark, manufacturer, or otherwise does not necessarily constitute or imply its endorsement, recommendation, or favoring by the United States Government or any agency thereof, or Battelle Memorial Institute. The views and opinions of authors expressed herein do not necessarily state or reflect those of the United States Government or any agency thereof.

\author{
PACIFIC NORTHWEST NATIONAL LABORATORY \\ operated by \\ BATTELLE \\ for the \\ UNITED STATES DEPARTMENT OF ENERGY \\ under Contract DE-AC05-76RL01830 \\ Printed in the United States of America \\ Available to DOE and DOE contractors from the \\ Office of Scientific and Technical Information, \\ P.O. Box 62, Oak Ridge, TN 37831-0062; \\ ph: (865) 576-8401 \\ fax: $(865) 576-5728$ \\ email: reports@adonis.osti.gov

\begin{abstract}
Available to the public from the National Technical Information Service, U.S. Department of Commerce, 5285 Port Royal Rd., Springfield, VA 22161 ph: (800) 553-6847 fax: (703) 605-6900 email: orders@ntis.fedworld.gov online ordering: http://www.ntis.gov/ordering.htm
\end{abstract}




\title{
Technical Review of Law Enforcement Standards and Guides Relative to Incident Management
}

\author{
RD Stenner ${ }^{1} \quad$ JR Stanton ${ }^{2}$ \\ R Salter $^{2} \quad$ D Fisher ${ }^{2}$
}

March 2009

Prepared for

U.S. Department of Homeland Security Science \& Technology Directorate Test, Evaluation, and Standards Division Standards Office under U.S. Department of Energy Contract DE-AC05-76RL01830 Emergency Preparedness and Response (EP\&R) Standards Development Project

Pacific Northwest National Laboratory

Richland, Washington 99352

${ }^{1}$ Pacific Northwest National Laboratory, Richland, Washington 99352

${ }^{2}$ Emergency Response Technology Integration Center, Fairfax Station, VA 22039 



\section{Executive Summary}

In an effort to locate potential law enforcement-related standards that support incident management, a team from the Pacific Northwest National Laboratory (PNNL) contacted representatives from the National Institute of Standards-Office of Law Enforcement Standards (NIST-OLES), National Institute of Justice (NIJ), Federal Bureau of Investigation (FBI), Secret Service, ASTM International committees that have a law enforcement focus, and a variety of individuals from local and regional law enforcement organizations. Discussions were held with various state and local law enforcement organizations.

The NIJ has published several specific equipment-related law enforcement standards that were included in the review, but it appears that law enforcement program and process-type standards are developed principally by organizations that operate at the state and local level. Input is provided from state regulations and codes and from external non-government organizations (NGOs) that provide "national" standards. The standards that are adopted from external organizations or developed independently by state authorities are available for use by local law enforcement agencies on a voluntary basis. The extent to which they are used depends on the respective jurisdictions involved. In some instances, use of state and local disseminated standards is mandatory, but in most cases, use is voluntary. Usually, the extent to which these standards are used appears to depend on whether or not jurisdictions receive certification from a "governing" entity due to their use and compliance with the standards. In some cases, these certification-based standards are used in principal but without certification or other compliance monitoring. In general, these standards appear to be routinely used for qualification, selection for employment, and training. In these standards, the term "Peace Officer" is frequently used to refer to law enforcement personnel.

This technical review of national law enforcement standards and guides identified the following four guides as having content that supports incident management:

- TE-02-02 Guide to Radio Communications Interoperability Strategies and Products

- OSHA 335-10N Preparing and Protecting Security Personnel in Emergencies

- NIJ 181584 Fire and Arson Scene Evidence: A Guide for Public Safety Personnel

- NIJ 181869 A Guide for Explosion and Bombing Scene Investigation

In conversations with various state and local law enforcement officials, it was determined that the following National Fire Protection Association (NPFA) standards are generally recognized and tend to be universally used by law enforcement organizations across the country:

- NFPA 1600 Standard on Disaster/Emergency Management and Business Continuity Programs

- NFPA 1561 Standard on Fire Department Incident Management Systems

- NFPA 472 Standard for Competence of Responders to Hazardous Materials/Weapons of Mass Destruction Incidents (2008 Edition)

- NFPA 473 Standard for Competencies for EMS Personnel Responding to Hazardous Materials/Weapons of Mass Destruction Incidents (2008 Edition) 
NFPA standards were reviewed in detail in an earlier 2007 review of potential incident management standards, so the detailed review results of these NFPA standards are not presented in this document. For detailed information on these NFPA standards and their relevance to incident management, refer to $E P \& R$ Standards Project: Technical Review of National Incident Management Standards (PNNL-16515).

The analysis performed in 2007 identified standards from various response disciplines (e.g., fire, emergency medical services, law enforcement, emergency management) that should be incorporated in incident management planning, training and conducting exercises as well as in actual response to promote consistency within the incident management system. Most of the findings from the 2007 review involved the application of existing standards to the incident management system. However, with respect to law enforcement, the analysis revealed potential gaps in operational-level standards regarding law enforcement's involvement in the incident management system. Specifically, the analysis identified the following needs/gaps:

- Law enforcement operational-level standards (which are different from specific law enforcement standard operating procedures) that enable public safety and security personnel to safely support emergency management and operations within a single and multi-jurisdictional incident. A standard is needed that addresses public safety and security operations (i.e., law enforcement) so that personnel are integrated more effectively into the management of multi-jurisdictional incident management/response operations.

- A documented incident command system that addresses all aspects of incident command for all responders in situations when public safety and security personnel are designated "Incident Commander.” The exception would be public safety and security organizations that use NFPA 1561 to define their incident command system.

- Increased law enforcement personnel understanding of existing and developing hazards (e.g., unknown hazardous materials, dirty bombs, biological events, technological hazards, etc.) to protect themselves and to manage public safety and security.

- A standard that addresses the transfer of incident command from one response discipline to another (e.g., discovery of methamphetamine laboratories, improvised explosive devices, suspicious packages, chlorine leaks, school incidents, natural gas ruptures, etc.). Again, the exception would be public safety and security organizations that use NFPA 1561 to define their incident command system.

- A standard that addresses preparations for unique law enforcement actions at public assembly facilities such as mass care/shelter venues being used for emergency management in catastrophic disaster response operations.

- A standard that specifies how multi-jurisdictional law enforcement assets will be integrated into complex emergencies and incidents.

- A standard that addresses potential inclusion of state and local law enforcement assets into a federally coordinated response.

- A standard that addresses how all responders will recognize and support law enforcement's need for the proper handling, control, and preservation of evidence and chain of custody at emergency incidents involving criminal acts. 
- Additional technical, operational or systems standards for law enforcement incident management may be necessary to address initial and ongoing training and exercises.

It is recommended, as a next step, that the NIJ and the International Association of Chiefs of Police (IACP) be engaged to validate/modify these identified gaps and explore options to fill them. The following is recommended as a potential approach to explore with the NIJ and IACP to fill the validated gaps:

\section{Suggested Approach}

- Develop (a) new standard(s) for law enforcement incident management that addresses the validated needs/gaps. The new standard(s) would be based on IACP principles and coordinated with existing incident management standards developed by other response disciplines and with other pertinent law enforcement organizations/associations’ principles (e.g., accrediting organizations, International Association of Directors of Law Enforcement Standards and Training, International Association of Law Enforcement Intelligence Analysts, Association of Public-Safety Communications Officials, and American Society for Industrial Security).

- Solicit NIJ and IACP advice on the appropriate standards development organization (e.g., NIJ, ASTM, American National Standards Institute, etc.) that should be tasked with development of the new standard(s). As deemed appropriate, involve selected NIJ and IACP members on the standards development organization's technical task group charged with development of the new standard(s). 



\section{Acronyms and Abbreviations}

\begin{tabular}{|c|c|}
\hline ANSI & American National Standards Institute \\
\hline APCO & Association of Public-Safety Communications Officials International \\
\hline ASTM & ASTM International (formerly known as American Society for Testing and Materials) \\
\hline CALEA & Commission on Accreditation for Law Enforcement Agencies \\
\hline DHS & U.S. Department of Homeland Security \\
\hline EMS & Emergency Medical Services \\
\hline EMAP & Emergency Management Accreditation Program \\
\hline EOC & Emergency Operations Center \\
\hline EOP & Emergency Operations Plan \\
\hline ESF & Emergency Support Function \\
\hline FEMA & Federal Emergency Management Agency \\
\hline HAZMAT & hazardous materials \\
\hline HEICS & Hospital Emergency Incident Command System \\
\hline HSEEP & Homeland Security Exercise Evaluation Program \\
\hline IACP & International Association of Chiefs of Police \\
\hline IADLEST & International Association of Directors of Law Enforcement Standards \\
\hline IALEIA & International Association of Law Enforcement Intelligence Analysts \\
\hline IAP & Incident Action Plan \\
\hline ICS & Incident Command System \\
\hline IEEE & Institute of Electrical and Electronics Engineers \\
\hline JCAHO & Joint Commission on the Accreditation of Healthcare Organizations \\
\hline JIC & Joint Information Center \\
\hline JIS & Joint Information System \\
\hline NEMA & National Emergency Management Association \\
\hline NENA & National Emergency Number Association \\
\hline NFPA & National Fire Protection Association \\
\hline NGO & non-government organization \\
\hline NIJ & National Institute of Justice \\
\hline NIMCAST & National Incident Management System Capability Assessment Support Tool \\
\hline NIMS & National Incident Management System \\
\hline NIST & National Institute of Standards and Technology \\
\hline NIST-OLES & National Institute of Standards and Technology-Office of Law Enforcement Standards \\
\hline NSA & National Sheriff's Association \\
\hline OSHA & Occupational Safety and Health Administration \\
\hline PNNL & Pacific Northwest National Laboratory \\
\hline POST & Police Officers Standards and Training \\
\hline SDOs & Standards Development Organizations \\
\hline SME & Subject Matter Experts \\
\hline UC & Unified Command \\
\hline
\end{tabular}





\section{Contents}

Executive Summary …....................................................................................................

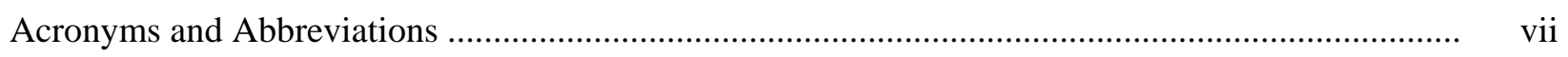

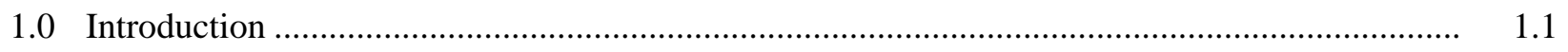

1.1 The Need for Incident Management Support Standards .................................................. 1.1

1.2 National Incident Management Standards Review of 2007 ............................................. 1.1

1.3 Law Enforcement Standards and Guides Identified for Review ...................................... 1.2

1.3.1 National Standards and Guidance ................................................................. 1.3

1.3.2 State, Local, and Non-Governmental Organization (NGO) Standards and Guides .. 1.5

1.3.3 Incident Response Versus Support.................................................................... 1.7

1.4 Brief Overview of the Technical Review Process............................................................... 1.7

1.5 Limitations of this Technical Review ............................................................................ 1.8

2.0 Summary of the Design and Development of the Automated Standards Review Tool............... 2.1

2.1 Tool Design Details.............................................................................................. 2.1

2.2 Integration of Existing Software and Tools ................................................................ 2.1

2.3 Incident Management Standards Review Criteria............................................................. 2.3

2.4 Automated Tool Output Tables ..................................................................................... 2.3

3.0 Technical Subject Matter Expert Review Process .............................................................

3.1 Technical SME Review Process ................................................................................... 3.1

3.2 Technical SME Review Method ..............................................................................

3.3 Technical Review Scoring Criteria ........................................................................ $\quad 3.4$

4.0 Law Enforcement Standards and Guides Review Results..................................................

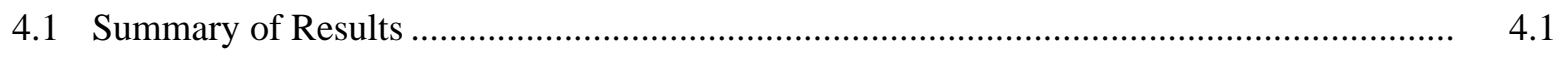

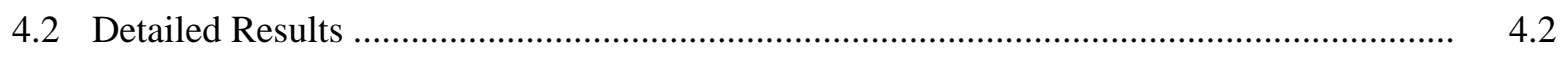

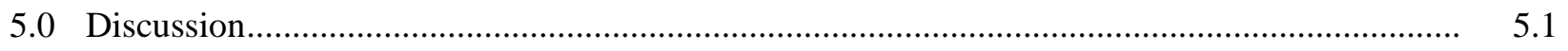

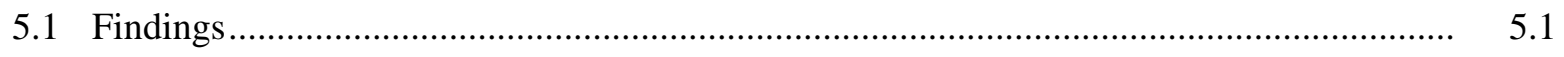

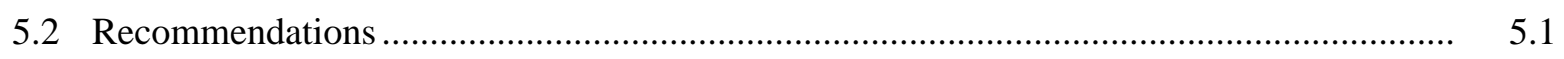

5.2.1 Suggested Approach................................................................................. 5.2

Appendix A Potential Incident Management Support Standards and Guides .................................. A.1

Appendix B Detailed Incident Management Component Criteria Search Terms ............................. B. 1

Appendix C Color-Coded Law Enforcement Standards and Guides Dashboard Tables ..................... C.1 


\section{Figures}

1.1 Categories of National Standards Supporting Incident Management .......................................... 1.2

1.2 Incident Response-Based Versus Incident Support-Based Perspective ..................................... 1.7

2.1 Components of the Standards Review Tool.......................................................................... 2.2

4.1 Law Enforcement Review Results Integrated Into the Framework for the Incident

Management Standards Diagram ......................................................................................... 4.2

\section{Tables}

2.1 Example Summary Output Table from the Review Tool

2.3

2.2 Example Detailed Output Table from the Review Tool 


\subsection{Introduction}

This report presents the results from a technical review conducted on several law enforcement standards and guides for their potential to support incident management. The review used a standards review tool developed by Pacific Northwest National Laboratory (PNNL) for the U.S. Department of Homeland Security (DHS) to help locate and screen potential standards and guides. Details on the design and operation of the PNNL standards review tool are discussed in the PNNL report, EP\&R Standards Project: Technical Review of National Incident Management Standards (PNNL-16515). PNNL-16515 also includes a description of the process used for the in-depth review of standards and guides selected by the tool for review by a subject matter expert (SME) technical review team. The complete technical review process is described in detail in PNNL-16515, but will be briefly summarized in this report.

\subsection{The Need for Incident Management Support Standards}

The importance and necessity for a full set of incident management guidelines and procedures that covers all response disciplines, as delineated in uniform national standards, was demonstrated by the impact of hurricanes that hit Florida in 2004, by hurricanes Katrina and Rita in 2005, and hurricanes Gustav and Ike in 2008. The need for such standards is also identified in the National Incident Management System (NIMS) and related Federal Emergency Management Agency (FEMA) documents. Throughout the history of emergency response to major disasters, especially where multiple response organizations were involved, there have been systemic problems in the consistency and uniformity of response operations. The identification/development of national standards that support the design and conduct of incident management is key to helping solve these systemic problems. That said, one must also recognize the unique function and operational differences among the various response disciplines that need to be systematically coordinated and managed at such incidents. Law enforcement is one such discipline with a unique structure and function that is different from others at an incident.

\subsection{National Incident Management Standards Review of 2007}

A FEMA list of 141 standards that potentially support incident management and NIMS was reviewed in 2007 and reported (PNNL-16515). In summary, a panel of SMEs performed a technical review of 61 of the 141 standards on the FEMA list and examined their specific applicability and relevance to NIMS. The remaining 80 standards were screened out by an automated review tool and subsequently eliminated because no connection to any of the specific NIMS component criteria was found in these standards. Of the 61 standards, 37 were developed by the National Fire Protection Association (NFPA), 19 were developed by ASTM International, and the remainder were from the American National Standards Institute (ANSI), the Joint Commission on Accreditation of Healthcare Organizations (JCAHO), the Institute of Electrical and Electronics Engineers (IEEE), the National Emergency Number Association (NENA), the Association of Public-Safety Communications Officials International (APCO) Project 25, National Institute of Justice (NIJ), and others. This technical review focused only on a standard's ability to align with the specific NIMS component criteria. It did not reflect on the quality of a standard or the purpose for which it was developed.

The 2007 technical review found 14 standards that fit into the three pre-identified incident management categories (i.e., systems, operational, and technical). A fourth category was added, as shown 
in Figure 1.1. The four functional categories are discussed in detail in PNNL 16515. The 14 incident management supportive standards identified were: NFPA 1600, NFPA 1561, NFPA 450, NFPA 472, NFPA 473, NFPA 1500, NFPA 1584, NFPA 1670, NFPA 1710, NFPA 1720, ASTM F1220, ASTM E2413, JCAHO-EM, and Hospital Emergency Incident Command System (HEICS). Only the NFPA 1600 (incident management system) and NFPA 1561 (incident command system) standards were considered broadly applicable across all disciplines. The JCAHO-EM, HEICS, ASTM 2413, ASTM F1220, NFPA 450, NFPA 473, NFPA 1710, NFPA 1720 are all associated with the medical response discipline category. The NFPA 472, NFPA 1500, NFPA 1584, NFPA 1670, NFPA 1710, and NFPA 1720 are all associated with the fire/hazardous materials (HAZMAT) discipline category. The FEMA list did not include any systems, operational, or technical category standards that supported either the law enforcement or the emergency management discipline categories. The technical review team was aware of ongoing efforts by various standards development organizations (SDOs) to develop incident management standards that support the emergency management category, but there appeared to be a gap in standards available that support the law enforcement community. Thus, a concerted effort was undertaken in 2008 to locate law enforcement standards that support incident management, the results of which are the subject of this report.
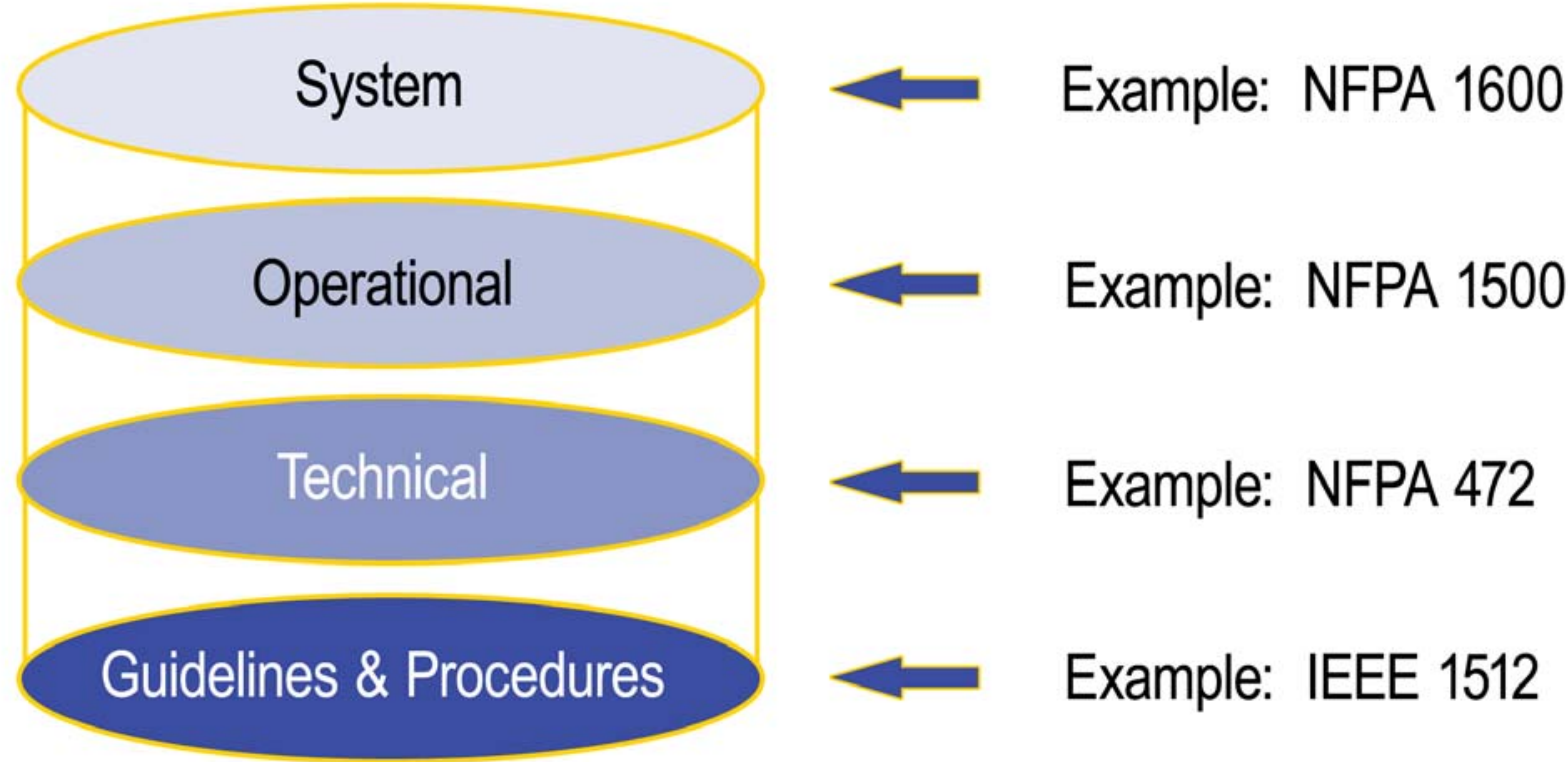

Figure 1.1. Categories of National Standards Supporting Incident Management

\subsection{Law Enforcement Standards and Guides Identified for Review}

In an effort to locate potential law enforcement-related standards that support incident management, the PNNL team contacted representatives from the National Institute of Standards-Office of Law Enforcement Standards (NIST-OLES), NIJ, Federal Bureau of Investigation (FBI), Secret Service, and ASTM International committees that have a law enforcement focus, and held discussions with a variety of individuals from local and regional law enforcement organizations.

From these discussions, it appears that process-related law enforcement standards are established and distributed by state-level organizations associated with the State Departments (or Commissions/ 
Divisions) of Criminal Justice. These state-level entities either adopt or develop standards and disseminate them to local law enforcement organizations. Through a survey of more than a dozen states, it was found that standards are developed and used for a variety of purposes including training, job performance, and mandatory or voluntary certification of law enforcement personnel and agencies. In addition to standards that are established at the state, and possibly at some local levels, it was also found that there are external associations and institutions that develop standards for both law enforcement agency certification as well as individual personnel performance. One example, the Commission on Accreditation for Law Enforcement Agencies (CALEA), was created to develop a set of law enforcement standards and to administer an accreditation process through which law enforcement agencies could demonstrate voluntarily that they meet professionally recognized criteria for excellence in management and service delivery.

Another example, the NIST-OLES, assists the criminal justice and public safety communities through the development of equipment performance standards, user guides, standard reference materials, and scientific research. Recently, the office has developed standards that address homeland defense initiatives including development of concealed weapons detection and imaging technologies. NIST has also developed related equipment performance standards for equipment such as metal detectors and protective equipment used by first responders to critical incidents.

Other examples of “external” standards and organizations include law enforcement analytic standards developed and distributed by the International Association of Law Enforcement Intelligence Analysts (IALEIA), Inc. and standards/principles developed by the International Association of Chiefs of Police (IACP) and the National Sheriff's Association (NSA). In addition, in 1973, the National Advisory Commission on Criminal Justice Standards and Goals developed national standards to "effect improvement in delivery of police service.” The Commission's report, Police, is a document that any police administrator can access and use to examine state-of-the-art operational practices. Suffice it to say, these examples of organizations that supplement standards and certification programs established at the state and local level appear to provide diverse sources for locating, and possibly adopting, law enforcement standards for use in respective jurisdictions.

It appears that among the standards developed by SDOs, whether state or external entities, most pertain to qualifications for positions in law enforcement, police training and personnel and agency certification. Exceptions may be found in a more extensive review of documents such as the Police publication identified above.

\subsubsection{National Standards and Guidance}

The following are examples of associations/organizations that produce nationally focused standards and guidance in various forms.

International Association of Chiefs of Police (IACP): Working with the U.S. Department of Justice, in 1987 the IACP established a National Law Enforcement Policy Center. The objective of the center was to assist law enforcement agencies across the country in developing and refining law enforcement policy. The policies produced are contained in a five-volume set available to State and local law enforcement agencies. While the content of these policies was not further investigated, it is assumed that they provide input to SDOs as the basis for selected standards development. 
International Association of Law Enforcement Intelligence Analysts (IALEIA), Inc.: Operating in concert with the U.S. Department of Justice, the Association produces standards that address such areas as collections, evaluation, data source, product evaluation, and analytic outcomes (among many others). Most of those examined pertained to the use of analytic products and processes for law enforcement and criminal investigation.

International Association of Directors of Law Enforcement Standards and Training (IADLEST): IADLEST is an international organization of training managers and executives dedicated to the improvement of public safety personnel. The Association serves as the national forum of peace officer standards and training agencies, boards, and commissions, as well as for statewide training academies throughout the United States. Its mission is to research, evaluate, and share information, ideas, and innovations that assist states in establishing defensible standards for employment and training of peace officers. In one document produced by IADLEST that was reviewed for this study, IADLEST Model Minimum Standards, IADLEST addresses minimum state standards for Police Officers Standards and Training (POST) agencies. Another document found in this portion of the research was the IADLEST Law Enforcement Sourcebook of Standards and Training Information in the United States. This sourcebook is an executive summary of IADLEST's national survey on law enforcement standards and training. The publication provides data on law enforcement officer standards, training, certification, and licensing.

The National Institute of Justice (NIJ): The standards program of the NIJ was established to provide the criminal justice community, purchasers, and manufacturers with information useful for the selection and evaluation of law enforcement, crime prevention, and procurement of correctional equipment. The standards are prepared by the OLES as part of NIJ's overall Law Enforcement and Corrections Standards and Testing Program, which includes developing standards and test protocols, testing equipment, and publishing test results. OLES is part of NIST, which is part of the Department of Commerce Technology Administration.

NIST Office of Law Enforcement Standards (NIST-OLES): The NIST-OLES provides standards for equipment including such items as still and video recognition systems, sirens, contraband technology, bomb disarmament, armored cars, gunlocks, and many others. Among those considered relevant (perhaps indirectly) to the incident management standards review project were standards that addressed critical incident technologies. Included were standards for public safety communications systems; detection, inspection, and enforcement technologies; weapons and protective systems; chemical and biological protection equipment; and performance testing standards.

The PNNL team received a full set of NIJ standards from NIST-OLES, which are included in the list of Potential Incident Management Support Standards and Guides provided in Appendix A. Examination of these NIJ standards clearly showed they were very detailed standards for equipment and did not address programmatic aspects of incident management. These standards were included in the review because they were related, but only at the detailed tactical equipment level. With this realization that the NIJ standards were focused on equipment, we began looking for NIJ guides. Several NIJ guides were found and are included in the Appendix A list. Twenty-nine potentially applicable ASTM International standards were also identified and are included in the Appendix A list. The remainder of the Appendix A list is made up of guides from the FBI, NIST-OLES, and similar organizations. 
The Commission on Accreditation of Law Enforcement Agencies (CALEA): The CALEA is a nonprofit organization formed in 1979 by four major law enforcement executive associations: the IACP; the National Organization of Black Law Enforcement Executives; the NSA; and, the Police Executive Research Forum. The Commission's principal publication originally contained more than 900 standards prepared by the four founding law enforcement membership associations. The standards were presented to the Commission by the founding institutions. Review by the CALEA included a field review by several hundred law enforcement agencies. The Commission adopted the standards in April 1983, in 1994 reduced the number to 436, but in 1999 increased the number of standards to 442. The standards are designed to improve a law enforcement agency's ability to prevent and control crime, increase agency effectiveness and efficiency in the delivery of law enforcement services, enhance cooperation and coordination with other law enforcement agencies, and raise citizen and employee confidence in the goals, objectives, policies and practices of the agency.

\subsubsection{State, Local, and Non-Governmental Organization (NGO) Standards and Guides}

Several state and non-government organizations (NGOs) were included, as a sampling, to determine the extent to which state governments, local governments, and NGOs develop and disseminate standards to be used for training and certification of law enforcement personnel and agencies. Discussions were also held with several state and county law enforcement personnel to obtain more details about how standards are integrated into the planning and operations within their agencies. The following discussions provide a sampling of state, local, and NGO law enforcement standards development activity across the country.

Alaska Police Standards Council: The goal of the Council is to "increase the overall effectiveness of the law enforcement and corrections communities by assuring a climate of professionalism and conscientious standards.” Accordingly, the Council overseas the development and promulgation of standards for law enforcement throughout the state.

Arkansas Office of Law Enforcement Standards (Arkansas-OLES): Operating under the authority of the Commission on Law Enforcement Standards and Training, the Arkansas-OLES produces and distributes regulations and standards addressing such areas as employment, training, certification of specialized police personnel, and certification of field training officers, including use of specialized equipment. Standards appear to address training and certification as opposed to job performance, per se; however, assumptions can be made that there is a direct relationship between the two.

California Commission on Peace Officer Standards and Training (POST): The Commission is responsible for establishing professional standards and ensuring access to high-quality training for over 85,000 law enforcement officers and dispatchers serving in police and sheriff's departments throughout the state.

Florida Criminal Justice Standards and Training Commission: The Commission establishes minimum standards for employment and training of law enforcement and correctional institution officers and establishes and maintains officer training programs and officer certification. It promulgates rules and procedures for law enforcement personnel throughout the state. 
New Jersey Department of Law and Public Safety: The Division of Criminal Justice, Law Enforcement Services Section, assists law enforcement by combining the development of law enforcement policy with standards for the operation of law enforcement agencies. It also addresses performance of police functions with the provision of technical assistance relative to specific needs within individual municipal police departments. Standards and operational guidelines are developed in areas such as police internal affairs, the handling of citizen complaints, and police vehicular pursuit.

Oklahoma State Bureau of Investigation: The Oklahoma State Bureau of Investigation recognizes the standards produced by the CALEA and the American Crime Laboratory Director's Association. The extent to which the output of these organizations is endorsed and used as actual standards throughout the state was not found. However, the fact that the state recognizes the standards implies that portions of the standards are adopted and used by state law enforcement agencies.

Texas Commission on Law Enforcement Officer Standards and Education: The Commission engages in functions similar to other commissions cited in this report. Two documents were found that contain standards produced (presumably) through the commission: The Juvenile Detention Officer Training Manual and the Peace Officers Standards and Training Field Training Manual for Law Enforcement Recruits. Most likely, the Commission has produced other similar standards and documents. However, the two cited above address executive and legal training requirements, credentialing and enforcement in homeland security, and responsibilities of unit and field commanders and are indicative of the practices used in Texas for standards development and dissemination.

Virginia Department of Criminal Justice Services: The Department includes a Standards and Training Section responsible for implementing regulations promulgated by the Criminal Justice Services Board pertaining to the minimum in-service training standards and requirements for enhancement of criminal justice services. Examples of the materials developed and distributed by the Standards and Training Section include the Criminal Justice Training Reference Manual and a variety of training objectives, criteria, and lesson plan guides. The latter includes guidelines on such matters as joint exercise of powers by political subdivisions, compliance with training standards, duties and powers of special police officers, patrol operations, investigations, defensive tactics, and weapons use. It also includes standards for operation of selected equipment such as radar, and it addresses performance objectives/standards for such functions as courtroom security and custodial duties. The Virginia Administrative Code, and specifically 6 VAC 20-20 through 20-100 and 20-60-100, relates to compulsory minimum training standards, including performance outcomes, for law enforcement officers.

Washington State Municipal Research and Services Center (MRSC): Among other things, the Center provides police and law enforcement performance standards and levels of service. Included in the documentation reviewed for this study were references to measuring service performance, community surveys, program goals and measures, and law enforcement community feedback.

\section{West Virginia Division of Criminal Justice Services (an agency of the Department of Military} Affairs): The Division is focused primarily on research, planning, and certification of law enforcement officers. Its functions are cross-cutting and include both state and local units of government and participants in the criminal justice system, which includes law enforcement, jails, courts, corrections, and community supervision. Information distributed by the Division, apparently in the form of reports and guidelines rather than standards, includes Establishing the Statistical Accuracy of Uniform Crime Reports in $W V$ and the Coordinated Plan for Preventing and Reducing Juvenile Crime in WV. 


\subsubsection{Incident Response Versus Support}

Two perspectives need to be in balance for a response that is truly consistent with the concepts and principles of incident management. One is the on-scene, incident response-based perspective, and the other the incident support-based perspective. Figure 1.2 shows this relationship. Standards and guides help to relate these two perspectives.

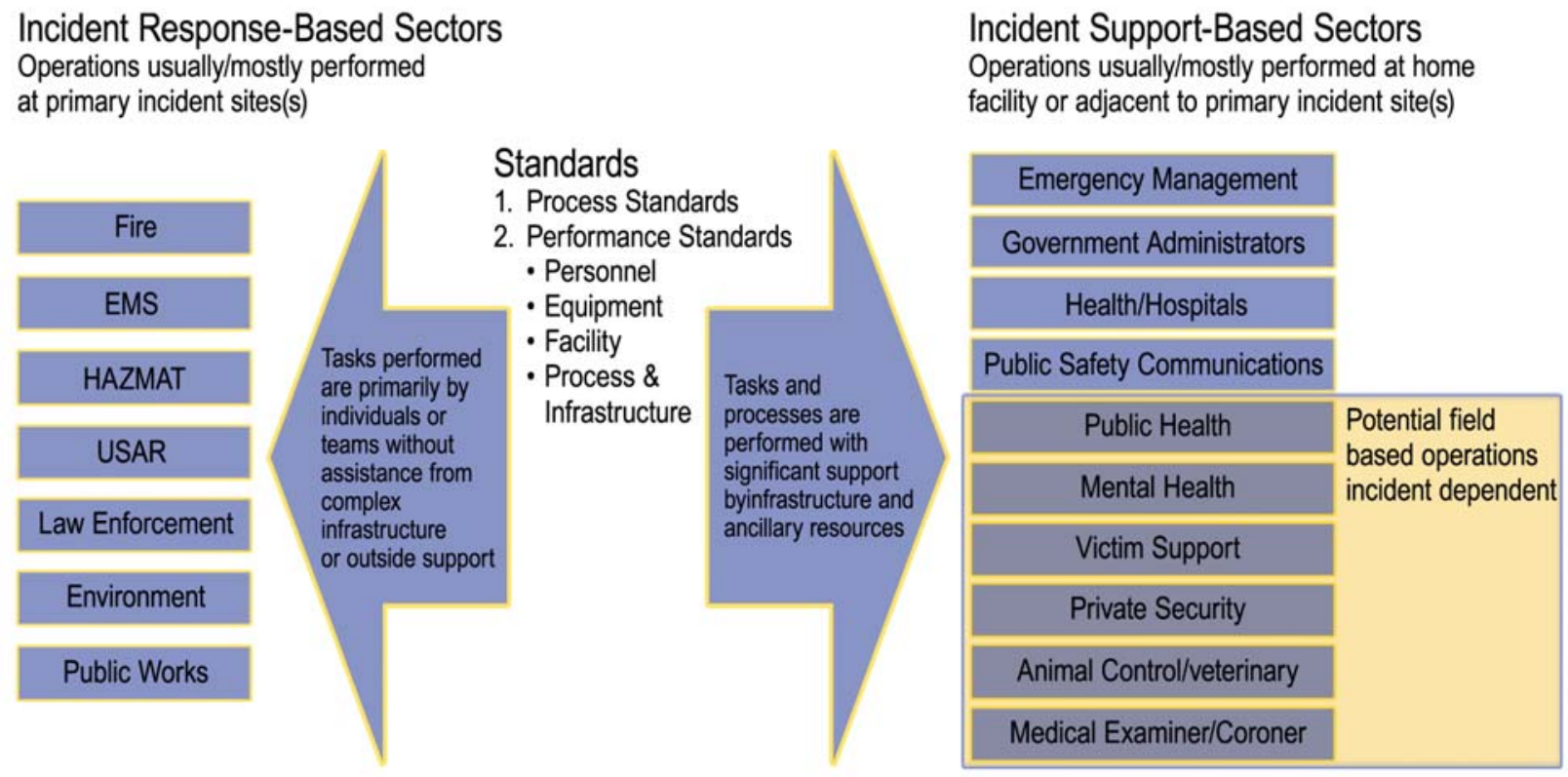

Figure 1.2. Incident Response-Based Versus Incident Support-Based Perspective

Another important perspective to consider when evaluating law enforcement standards that support incident management is the organizational difference between law enforcement and other responder organizations.

\subsection{Brief Overview of the Technical Review Process}

The technical review of the law enforcement standards and guides listed in Appendix A was conducted in a dynamic and fluid environment. Law enforcement organizations, in cooperation with a significant number of other first responder organizations at both the public and private sector level, continue to develop strategies and procedures that enhance coordination and communication. At the same time, policy makers are modifying incident management terminologies, implementation strategies, guidance, and educational processes that support preparedness, training, response, and mitigation. The technical review was designed to identify standards and guides that apply to developing and implementing incident management within this changing environment.

The technical review utilized the standards review tool, discussed previously, that PNNL developed for the DHS. As previously stated, the purpose of the automated tool was to help locate and screen potential standards and guides that relate to incident management. The technical review also included an in-depth review of tool-selected standards and guides by a SME technical review team (a detailed description of the complete technical review process is provided PNNL-16515). 
The technical review process enabled the review of as many potential standards and guides as necessary to ensure a basic consistency among the various emergency management authorities without pre-determining or forcing any specific viewpoint or procedure. For the most part, the standards and guides identified will assist with preparedness and response activities.

\subsection{Limitations of this Technical Review}

The technical review has certain limitations. The primary limitation is that these standards and guides were developed for a purpose other than supporting a national-level incident management system. There was no expectation that the processes, principles, and terminology in these standards and guides would be consistent. This limitation is not a deficiency in either the standards/guides or their development process, but instead represents an evolving and maturing of emergency management principles and the incremental establishment of a consistent nationwide incident management system. For example, the review found many instances where a standard or guide could be updated to include incident management terminology in the definitions section and in the body of the standard itself. In other instances, standards intended for use by specific response functions (e.g., fire, emergency medical services [EMS], law enforcement, etc.) did not address the responsibility of the function to coordinate within a chain of command or incident management structure. These examples illustrate that a standard or guide may be perfectly suited to the situation for which it was developed but does not include state-of-the-art references to incident management systems, processes or structures.

Our technical review process was not designed to identify specific remedial actions for SDOs to take in relation to updating their standard or guide. Also, the review was technically focused and did not attempt to address usability at the jurisdictional level. The identified standards and guides should be examined further for their ability to technically link and support the various components and criteria of existing incident management systems (i.e., NIMS) and should be reviewed for their ability to be implemented and integrated into existing emergency management programs and organizations nationwide. 


\subsection{Summary of the Design and Development of the Automated Standards Review Tool}

\subsection{Tool Design Details}

As previously mentioned, the detailed design and construction of the automated standards review tool is discussed in detail in PNNL-16515. However, its design will be briefly discussed in this section for clarity in understanding the technical review process. In designing the tool, it was clear that it could not replace the knowledge and experience of qualified experts in incident and emergency management. Thus, the tool was designed to consistently locate, sort, and classify (summarize) information based on its relationship to incident management criteria, which was specified in a series of word-string relationships. These word-string relationships were developed from a set of detailed criteria derived from the NIMS document and the NIMS Capability Assessment Support Tool (NIMCAST).

\subsection{Integration of Existing Software and Tools}

The tool was initially designed around PNNL's IN-SPIRE ${ }^{\mathrm{TM}}$ software system using its ability to search large volumes of text and identify informational relationships. This word relationship search capability was linked with a text extraction process to identify and extract text from the published format of the different standards and guides (i.e., PDF, DOC, HTML formats). A text editor (i.e., TextPad ${ }^{\mathrm{TM}}$ ) was used to clean up and prepare the text for conversion into a DocBook XML schema. AsciiDoc ${ }^{1}$ was used for that conversion. After the document content was converted into a valid XML format, it was imported into a native-XML database $\left(\mathrm{eXist}^{2}\right)$ for analysis and post-processing. Also stored in this database were specific queries derived from the detailed NIMS criteria. Results were uploaded to a web service that delivers summary results in a detailed report and scores information to a PHP code and a MySQL database, where the scoring results were stored. A general diagram of the tool components is shown in Figure 2.1.

\footnotetext{
${ }^{1}$ AsciiDoc is a markup language. It requires installation of a special AsciiDoc converter program that can convert an AsciiDoc document in HTML, PDF, and other formats. The converter program is written in Python. AsciiDoc is released under the GNU General Public License.

${ }^{2}$ eXist is an open source database management system entirely built on XML technology. eXist uses XML and XML queries to manage data rather than using SQL or the standard SQL 92. eXist tends to be bigger than most database formats, which does impact performance.
} 


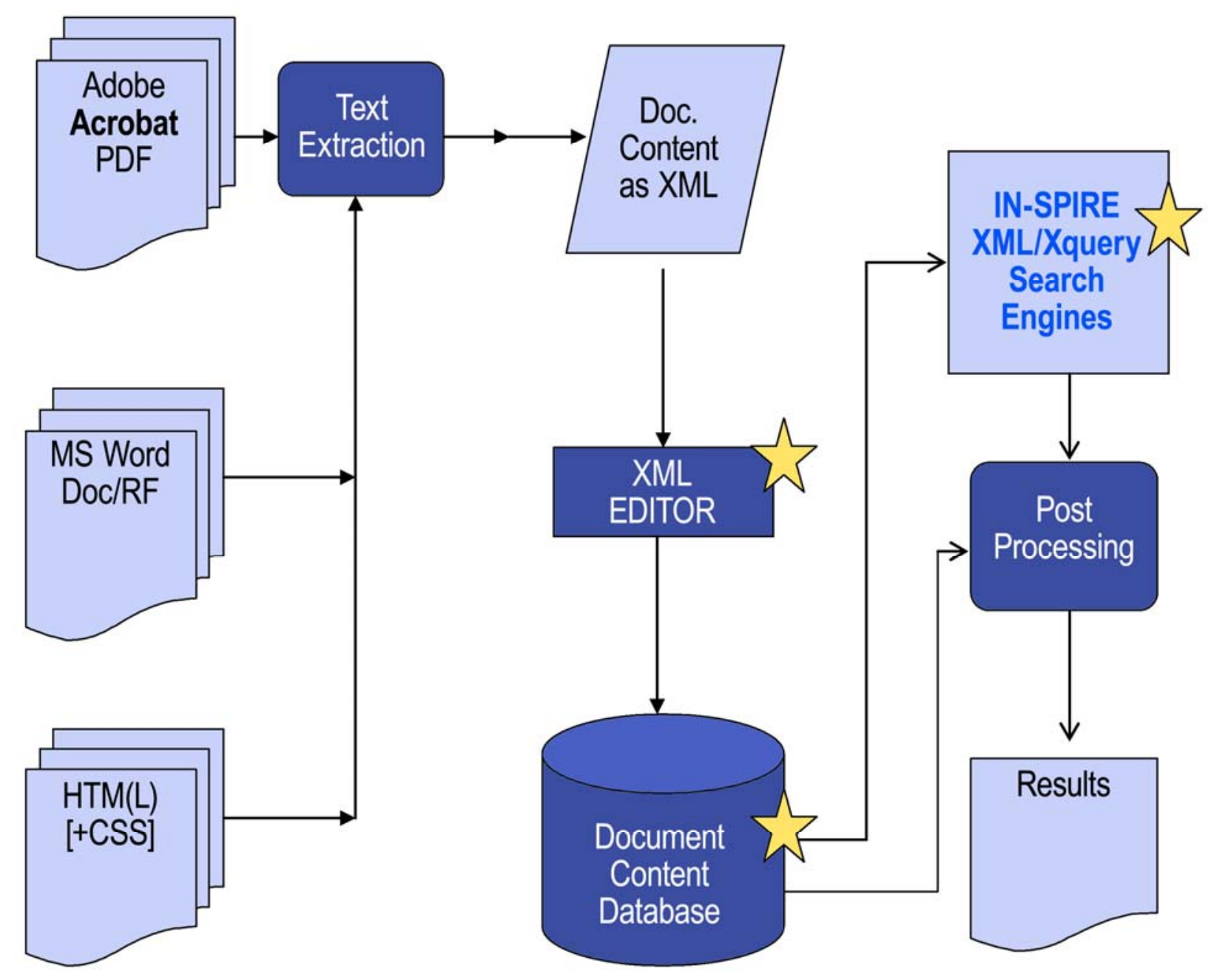

Figure 2.1. Components of the Standards Review Tool

The following word relationship routines were incorporated into the tool:

Match - searches for text that exactly matches the search criteria, including order-of-word string and form of words

Fuzzy - searches for text that exactly matches the search criteria, including order-of-word string, but searches considering various forms of the words in the word string (e.g., monitor, monitoring, monitored)

Near - searches for text containing all the words in the word string criteria in the specific order with less than one word between them; it is case-sensitive

$\boldsymbol{\&}=-$ searches for text containing all the words in the word string criteria in any order without regard to distance between them.

Selecting the best word relationship search routine to use depends on the intent of the search. For example, if one is looking for an exact title or word combination, the Match routine is best. The flexibility of a search progresses through the list of search routines; the \&= search is the most flexible. The trade-off that must be balanced throughout the list is the tool's selection of duplicate findings. After some trial and error, we used the $\&=$ routine for our review of the standards on the NIMS Division List 
because it was easy to spot and remove duplicates. The $\&=$ routine provided the most assurance of finding text relating to the NIMS criteria.

\subsection{Incident Management Standards Review Criteria}

To conduct a consistent in-depth technical review of each standard, it was necessary to develop detailed and specific criteria that reflected all of the requirements necessary for consistency with incident management needs. The NIMS document and NIMCAST were used as the baseline documents to derive these criteria. NIMCAST provides a very detailed set of checklists for compliance with NIMS, which were very helpful in deriving specific criteria. The detailed NIMS search-term criteria are listed in Appendix B.

\subsection{Automated Tool Output Tables}

The review tool produces both summary and detailed output tables designed for the technical SME team to use in reviewing those standards and guides selected by the tool. Table 2.1 is an example summary output table. The red text shows how an entry in this summary table can be followed to Table 2.2 for more detail.

Table 2.1. Example Summary Output Table from the Review Tool

\begin{tabular}{|c|c|c|c|}
\hline & \multirow[b]{2}{*}{ Component } & \multicolumn{2}{|c|}{ Document } \\
\hline & & $\begin{array}{c}\text { NFPA } \\
1561\end{array}$ & $\begin{array}{c}\text { NEPA } \\
1600\end{array}$ \\
\hline I & Preparedness & & \\
\hline I-A & Preparedness Organizations and Programs & $\begin{array}{l}3 \text { near } \\
4 \&=\end{array}$ & $\begin{array}{l}5 \text { near } \\
6 \&=\end{array}$ \\
\hline I-B & Implement Emergency Preparedness Cycle & $\begin{array}{l}4 \text { near } \\
4 \&=\end{array}$ & $\begin{array}{l}3 \text { near } \\
4 \&=\end{array}$ \\
\hline II & Communications and Information Management & & \\
\hline II-A & Communications and Incident Management & $\begin{array}{l}23 \text { near } \\
24 \&=\end{array}$ & $\begin{array}{l}6 \text { near } \\
7 \&=\end{array}$ \\
\hline II-B & Effective Communications, Information Management and Information Sharing & $\begin{array}{l}4 \text { near } \\
4 \&=\end{array}$ & $\begin{array}{l}1 \text { near } \\
1 \&=\end{array}$ \\
\hline II-C & $\begin{array}{l}\text { Establishing and Maintaining a Common Operating Picture and Ensuring } \\
\text { Accessibility and Interoperability }\end{array}$ & & \\
\hline II-D & Managing Interoperable Communications and Data & $1 \&=$ & \\
\hline
\end{tabular}

The Near and $\&=$ search routines were applied to a portion of the NIMS criteria to produce the example output summary shown in Table 2.1. The difference in resulting search routine findings is shown in this example. An example detailed output table is shown in Table 2.2. The detailed output example is that of the specific NIMS component/criteria grouping shown in red. 
Table 2.2. Example Detailed Output Table from the Review Tool

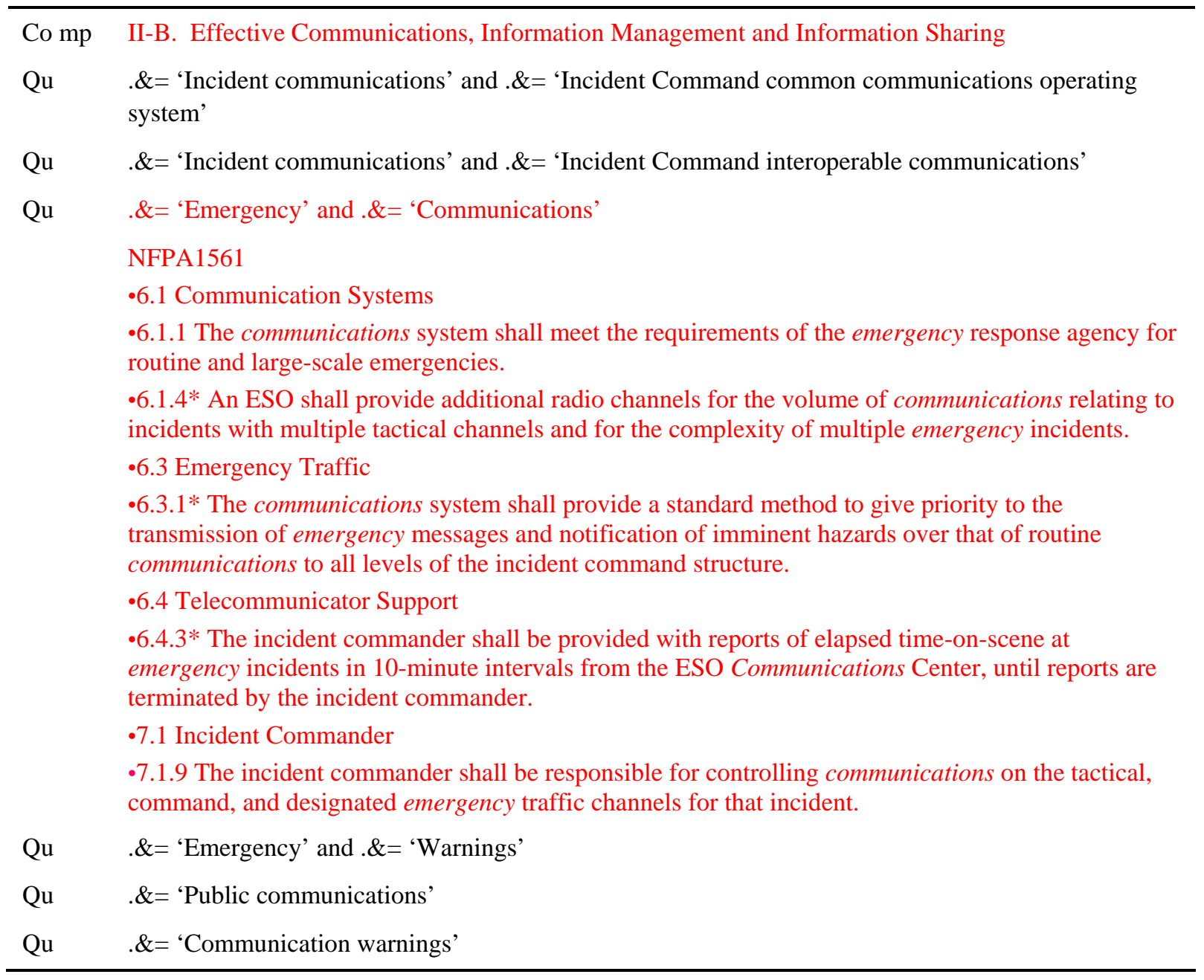




\subsection{Technical Subject Matter Expert Review Process}

\subsection{Technical SME Review Process}

This section describes the process the SME team used to review the 107 law enforcement-related standards and guides selected by the tool for potential applicability to incident management. The technical SME review process consisted of four phases:

- Phase 1: The team collectively defined criteria to assess the ability of each standard to meet incident management support objectives, i.e., the extent to which a specific standard, or parts of a standard, contributes to the establishment of a uniform and consistent incident management system across the nation.

- Phase 2: Each team member read each standard or guide in its entirety to understand the specific content of each document.

- Phase 3: The team collectively developed a color-coded "dashboard" matrix compatible with the search tool criteria, which enabled a visual presentation of an extremely large amount of complex information to show where gaps may exist in the coverage of a particular standard or guide.

- Phase 4: The team collectively discussed each standard or guide, applying the criteria and developing a consensus on the applicability of the whole standard/guide or parts of each standard/guide, reaching a consensus on color-coding, and agreeing on comments to be included in the analysis.

The SME team used the 2007 review of NFPA 1600, Standard on Disaster/Emergency Management and Business Continuity Programs and NFPA 1561, Standard on Emergency Services Incident Management System as the system standards basis for evaluating these law enforcement standards and guides. These two standards (i.e., NFPA 1600 and NFPA 1561) were determined to possess overarching or "system" content that supports incident preparedness and management regardless of functional incident response activities (fire, EMS, law enforcement, etc.). By beginning with "system" standards, the team was able to develop a set of criteria that could be consistently applied across all standards.

The incident management component criteria categories used for the key word search were also used to focus the group discussion, analysis, and color-coding for all standards. These component criteria categories were used in the keyword search and by the team to ensure that all standards were assessed against the component criteria for applicability to incident management. Those categories are:

- Preparedness Organizations and Programs

- Implement Emergency Preparedness Cycle

- Communications and Information Management

- Effective Communications, Information Management, and Information Sharing

- Establishing and Maintaining a Common Operating Picture and Ensuring Accessibility and Interoperability

- Managing Interoperable Communications and Data 
- Resource Management

- Categorizing Resources

- Effective Management of Resources

- Inventorying Process

- Resource Acquisition

- Mobilizing Resources

- Recovering Resources

- Reimbursement

- Command and Management

- Field Command and Management Functions

- Modular, Scalable Incident Command System

- Interactive Management Components

- Measurable objectives

- Management Characteristics

- Modular Organization

- Management by Objectives

- Incident Action Plan

- Manageable Span of Control

- Pre-designated Incident Locations and Facilities

- Comprehensive Resource Management

- Integrated Communications

- Establishment and Transfer of Command

- Unified Command

- Incident Management Accountability

- Information and Intelligence Management

- Incident Command System (ICS) Organization and Operations

- ICS Single Command (IC)

- ICS Unified Command (UC)

- ICS Incident Action Plan (IAP)

- ICS Resources

- ICS Area Command 
- Emergency Operations Center

- Joint Information System (JIS) and Center (JIC)

- Incident Management Hazard Identification, Risk Management, and Impact Analysis

- Supporting Technologies.

The SME technical review team identified five consensus criteria (i.e., scope, relevance, operational application, organization level, and completeness) for use in distilling and managing the review process, which led to the development of the color-coding process.

By bifurcating the review (i.e., using the review of NFPA 1600 and NFPA 1561 system standards first, followed by function-specific standards), the team was able to use the conceptualized framework developed in the 2007 review for these law enforcement-related standards and guides. This approach allowed the team to expand the review framework from a simplistic color-coding of all standards to one that recognizes inherent differences in the purpose of standards. System standards have applicability across the full range of first responder functions (emergency management, fire, EMS, law enforcement, medical, etc.); however, function-specific standards may have limited applicability to the overall incident management system and, instead, relate to only one (or more) of the individual responder disciplines. In this review, the standards were examined for their applicability to the law enforcement discipline.

The SME team used the same incident management framework diagram developed in the 2007 review to facilitate its discussion and reviews and enable a visual representation of a hierarchy of system applicability, function-specific applicability, and interrelationships among standards for coverage or gap analysis. The SME team divided the reviewed standards and guides into four categories: system standards, operational standards, technical standards, and professional guidance/procedural (tactical) standards. Due to the specific nature of this review, all standards or guides were related to the law enforcement sector. The Federal Emergency Support Function (ESF) of primary focus for this review is ESF \#13, which is as follows:

\section{ESF \#13 - Public Safety and Security}

- Facility and Resource Security

- Security Planning and Technical and Resource Assistance

- Public Safety/Security Support

- Support to Access, Traffic, and Crowd Control

ESF Coordinator: U.S. Department of Justice

\subsection{Technical SME Review Method}

This section describes the methodology (steps) the SME team used to review the 107 standards and guides identified as having the potential to directly support incident management. The 12-step review process is as follows:

1. Identification of keywords and concepts found within incident management component criteria; 
2. Identification of law enforcement standards and guides appropriate for review;

3. Application of the search tool to identify the presence and frequency of keyword phrases in each standard or guide using the incident management component criteria derivatives;

4. Development of a matrix for each standard to record the presence of keyword/phrase relationship "hits" found in the respective standard or guide;

5. Intensive reading of each standard or guide by each member of the team to assess the applicability of the standard/guide and its content to incident management;

6. Development of an initial assessment of each standard or guide by each SME;

7. Review and discussion of each standard or guide by the entire team using a set of consensus criteria: scope, relevance, operational application, completeness, and ability of the standard/guide to contribute to incident management integration;

8. Production of a color-coded matrix for each standard/guide grouped by incident management component criteria on the vertical axis and the consensus criteria on the horizontal axis; the colorcoding was assigned using the criteria of Step 7, and color assignments were made based on the following rules: 4 of the 5 criteria found rated green, 3 of 5 rated light green, 2 of 5 rated yellow, 1 of 5 rated orange, and 0 of 5 rated red;

9. Comparison of each SME finding with the presence of keywords or concepts found by the incident management component criteria search tool to confirm the presence or absence of specific language;

10. Capturing a brief information point describing the rationale/conclusion of the team;

11. Review of the findings by the full SME team to help ensure consistency within the group process; and

12. Placement of the SME findings into a composite matrix of all standards, all criteria, by code, with comments.

The results of this analysis were captured in a database integral to the tool for future retrieval and application.

\subsection{Technical Review Scoring Criteria}

The technical SME review used the following criteria for color-code scoring of each standard. Integration and completeness were evaluated together in the color-coding process.

SCOPE: The degree to which a standard/guide (or part thereof) covers the incident management process, generally including "who" and "what." Many standards are not intended to cover the full range of incident management processes but rather are limited in scope as stated in the introduction to the standard. Examples of such limitations include applicability to "emergency service organizations" but not “emergency operations centers," “deployment of resources” but not “acquisition, allocation or recovery of resources,” or requirements for "planning” but not a "plan.”

RELEVANCE: The degree to which a standard/guide (or part thereof) establishes its rationale in incident management processes, generally including the "why" of the standard. Many standards are specifically oriented toward a specific group of personnel or a specific function but cannot be generalized to other groups, functions, or organizational levels. Examples of such limitation include applicability to 
emergency management and incident management system processes versus applicability to a specific first responder group (fire, EMS, etc.).

OPERATIONS/HOW: The degree to which a standard/guide (or part thereof) states the activities to be performed in the context of incident management processes. Many standards do not identify the actions to be taken by response personnel, deferring these descriptions to standard operating procedures, and do not address the integration of response actions with incident management processes.

ORGANIZATION LEVEL: The degree to which a standard/guide (or part thereof) identifies the placement of the entity in a command, or authority, decision-making structure. Many standards/guides do not address the responsibility of the entity responsible for implementing the standard within a chain of command.

INTEGRATION: The degree to which a standard/guide (or part thereof) recognizes and states the requirement to participate as a component in an overall emergency management strategy or operation, with associated communication, cooperation, and coordination up and down a chain of command or incident management process.

COMPLETENESS: The degree to which the standard "fills out" the incident management system and processes, enabling a smooth coordination of preparedness activities and emergency management processes. Many standards do not specifically address a systems approach to executing the targeted responsibilities or do not use terminology consistent with NIMS. 



\subsection{Law Enforcement Standards and Guides Review Results}

\subsection{Summary of Results}

In the search for law enforcement standards that support incident management, the extent to which the law enforcement community operates somewhat differently than the fire service and other response disciplines was obvious. There are some pertinent federal standards, primarily produced by the NIJ/OLES, but law enforcement standards tend to be developed principally by organizations that operate at the state level. Input is provided from state regulations and codes and from external NGOs that provide "national" standards. The standards that are adopted from external organizations or developed independently by state authorities are available for use by local law enforcement agencies; however, the extent to which they are used depends on whether or not respective jurisdictions involved choose to employ them. In some instances, use of state disseminated standards is mandatory while in others it is voluntary. Usually, the extent to which they are used appears to depend on whether or not jurisdictions receive certification from a "governing" entity due to their use and compliance with the standards. Standards appear to be routinely used for qualification and selection for employment and for training. In these standards, use of the term "Peace Officer" is frequently used to refer to law enforcement personnel.

Standards developed on the federal level tend to be equipment-specific. Incident management processes and procedures developed at the federal level tend to be provided in the form of guides. Thus, we expanded our review to include both standards and guides.

From the technical review of federally produced law enforcement standards and guides, the following four guides were identified as having content that supports incident management:

- TE-02-02 Guide to Radio Communications Interoperability Strategies and Products

- Occupational Safety and Health Administration (OSHA) 335-10N Preparing and Protecting Security Personnel in Emergencies

- NIJ 181584 Fire and Arson Scene Evidence: A Guide for Public Safety Personnel

- NIJ 181869 A Guide for Explosion and Bombing Scene Investigation

In conversations with various state and local law enforcement officials, it was determined that the following NPFA standards are generally recognized and tend to be universally used by law enforcement organizations across the country:

- NFPA 1600 Standard on Disaster/Emergency Management and Business Continuity Programs

- NFPA 1561 Standard on Fire Department Incident Management Systems

- NFPA 472 Standard for Competence of Responders to Hazardous Materials/Weapons of Mass Destruction Incidents (2008 Edition)

- NFPA 473 Standard for Competencies for EMS Personnel Responding to Hazardous Materials/Weapons of Mass Destruction Incidents (2008 Edition) 
NFPA standards were reviewed in detail in the 2007 review; consequently, the detailed review results of these NFPA standards are not presented in this document. For detailed information on these NFPA standards and their relevance to incident management refer to PNNL-16515.

Figure 4.1 presents an overall summary of the incident management standards and guides and where they fit into the "big picture" of incident management.

This technical review process focused only on a standard's ability to align with the specific NIMS component criteria. It does not reflect on the value of a standard and the purpose for which it was developed (i.e., this technical review does not address the quality of a standard or applicability to the response community outside its ability to support NIMS).

\section{A Framework for Incident Management Standards}

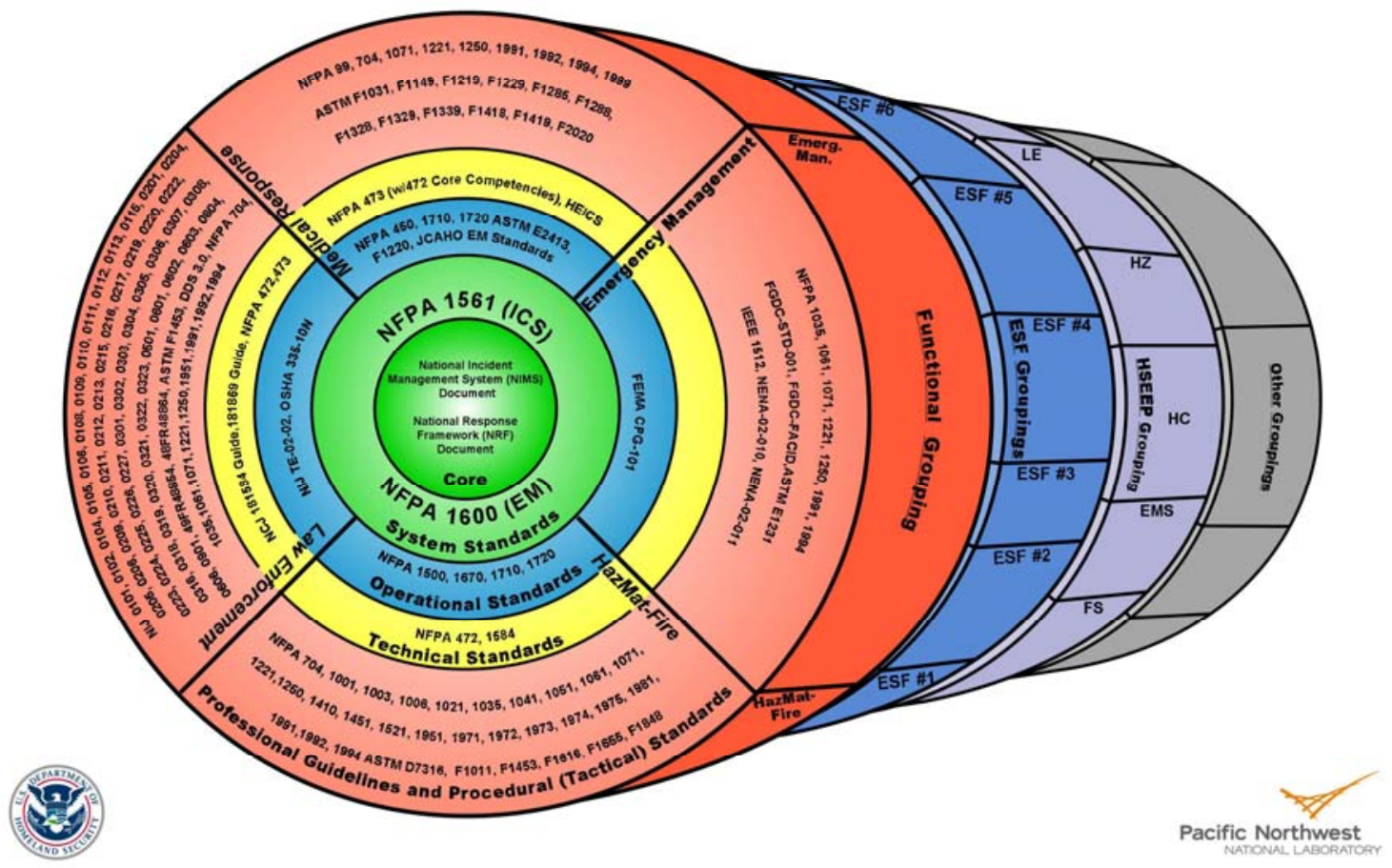

Figure 4.1. Law Enforcement Review Results Integrated Into the Framework for the Incident Management Standards Diagram

\subsection{Detailed Results}

This section presents the detailed results from the team's technical review of 107 agency standards and guides identified as potentially supporting incident management.

Using the technical review process and color-coding discussed in Sections 2 and 3, color-coded dashboard tables were prepared for the Law Enforcement category. The purpose of the dashboard tables is to provide, at a quick glance, which standards or guides tend to align best with each of the respective 
incident management components and criteria. Green means it aligns well with the respective incident management component and criteria. Light green means it aligns fairly well, but is missing a couple of criteria. Yellow means it is missing three of the criteria. Orange means it is missing four of the criteria. Red means it does not address any of the five criteria very well. However, a red coding does not mean a standard is not a quality standard addressing the purpose for which it was designed. It means only that it did not align with the incident management criteria very well. The standards in the Professional Guidelines and Procedures grouping all received a red coding; however, they are very valuable to incident management for the detailed purpose for which they were designed. The detailed results are presented in Appendix $\mathrm{C}$ tables showing the color-coding for each standard, the specific sections of the standard that apply to the respective incident management components/criteria, and a list of the criteria missing for each standard that is color-coded other than green or red. 



\subsection{Discussion}

\subsection{Findings}

The following law enforcement standard gaps were identified as a result of the technical review:

- Law enforcement operational-level standards (which are different from specific law enforcement standard operating procedures) that enable public safety and security personnel to safely support emergency management and operations within a single and multi-jurisdictional incident.

- A standard is needed that addresses public safety and security operations (i.e., law enforcement) so that personnel are integrated more effectively into the management of multi-jurisdictional incident management/response operations.

- A documented incident command system that addresses all aspects of incident command for all responders in situations when public safety and security personnel are designated "Incident Commander.” The exception would be public safety and security organizations that use NFPA 1561 to define their incident command system.

- Increase law enforcement personnel's understanding of existing and developing hazards (e.g., unknown hazardous materials, dirty bombs, biological events, technological hazards, etc.) to protect themselves and to manage public safety and security.

- A standard is needed that addresses the transfer of incident command from one response discipline to another (e.g., discovery of methamphetamine laboratories, improvised explosive devices, suspicious packages, chlorine leaks, school incidents, natural gas ruptures, etc.). Again, the exception would be public safety and security organizations that use NFPA 1561 to define their incident command system.

- A standard that addresses preparations for unique law enforcement actions at public assembly facilities such as mass care/shelter venues being used for emergency management in catastrophic disaster response operations.

- A standard that specifies how multi-jurisdictional law enforcement assets will be integrated into complex emergencies and incidents.

- A standard that addresses potential inclusion of state and local law enforcement assets into a federally coordinated response.

- A standard that addresses how all responders will recognize and support law enforcement's need for the proper handling, control, and preservation of evidence and chain of custody at emergency incidents involving criminal acts.

\subsection{Recommendations}

It is recommended, as a next step, that the NIJ and IACP be engaged to validate/modify these identified gaps and explore options to fill them. The following is recommended as a potential approach, to explore with the NIJ and IACP, for filling the validated gaps. 


\subsubsection{Suggested Approach}

Develop a new standard(s) for law enforcement incident management that addresses the validated needs/gaps. The new standard(s) would be based on IACP principles and coordinated with existing incident management standards developed by other response disciplines and with other pertinent law enforcement organizations/associations' principles (e.g., accrediting organizations, IADLEST, IALEIA, APCO, and American Society for Industrial Security). Solicit NIJ and IACP advice on the appropriate standards development organization (e.g., NIJ, ASTM, ANSI, etc.) that should be tasked with development of the new standard(s). As deemed appropriate, involve selected NIJ and IACP members on the standards development organization's technical task group charged with development of the new standard. 


\section{Appendix A}

\section{Potential Incident Management Support Standards and Guides}





\section{Appendix A}

\section{Potential Incident Management Support Standards and Guides}

\begin{tabular}{|c|c|}
\hline E1967 & $\begin{array}{l}\text { Standard Test Method for the Automated Determination of Refractive } \\
\text { Index of Glass Samples Using the Oil Immersion Method and a Phase } \\
\text { Contrast Microscope }\end{array}$ \\
\hline E1969 & $\begin{array}{l}\text { Standard Guide for Microcrystal Testing in the Forensic Analysis of } \\
\text { Methamphetamine and Amphetamine }\end{array}$ \\
\hline E2057 & $\begin{array}{l}\text { Standard Specifications for Preparation of Laboratory Analysis Requests in } \\
\text { Sexual Assault Investigations }\end{array}$ \\
\hline E2123 & $\begin{array}{l}\text { Standard Practice for the Transmittal of Evidence in Sexual Assault } \\
\text { Investigation }\end{array}$ \\
\hline E2124 & $\begin{array}{l}\text { Standard Practice for the Specification for Equipment and Supplies in } \\
\text { Sexual Assault Investigations }\end{array}$ \\
\hline E2224 & Standard Guide for Forensic Analysis of Fibers by Infrared Spectroscopy \\
\hline E2225 & Standard Guide for Forensic Examination of Fabrics and Cordage \\
\hline E2227 & $\begin{array}{l}\text { Standard Guide for Forensic Examination of Non-Reactive Dyes in Textile } \\
\text { Fibers by Thin-Layer Chromatography }\end{array}$ \\
\hline E2228 & Standard Guide for Microscopic Examination of Textile Fibers \\
\hline E2326 & Standard Practice for Education and Training of Seized-Drug Analysts \\
\hline E2327 & $\begin{array}{l}\text { Standard Practice for Quality Assurance of Laboratories Performing } \\
\text { Seized-Drug Analysis }\end{array}$ \\
\hline E2329 & Standard Practice for Identification of Seized Drugs \\
\hline E2330 & $\begin{array}{l}\text { Standard Test Method for Determination of Trace Elements in Glass } \\
\text { Samples Using Inductively Coupled Plasma Mass Spectrometry (ICP-MS) }\end{array}$ \\
\hline E2548 & $\begin{array}{l}\text { Standard Guide for Sampling Seized Drugs for Qualitative and Quantitative } \\
\text { Analysis }\end{array}$ \\
\hline F0792 & $\begin{array}{l}\text { Standard Practice for Evaluating the Imaging Performance of Security } \\
\text { X-Ray Systems }\end{array}$ \\
\hline F0903 & $\begin{array}{l}\text { Standard Test Method for Resistance of Materials Used in Protective } \\
\text { Clothing to Penetration by Liquids }\end{array}$ \\
\hline F1001 & $\begin{array}{l}\text { Standard Guide for Selection of Chemicals to Evaluate Protective Clothing } \\
\text { Materials }\end{array}$ \\
\hline F1052 & Standard Test Method for Pressure Testing Vapor Protective Ensembles \\
\hline F1154 & $\begin{array}{l}\text { Standard Practices for Qualitatively Evaluating the Comfort, Fit, Function, } \\
\text { and Integrity of Chemical-Protective Suit Ensembles }\end{array}$ \\
\hline F1186 & Standard Classification System for Chemicals According to Functional \\
\hline
\end{tabular}




\begin{tabular}{|c|c|}
\hline & Groups \\
\hline F1194 & $\begin{array}{l}\text { Standard Guide for Documenting the Results of Chemical Permeation } \\
\text { Testing of Materials Used in Protective Clothing }\end{array}$ \\
\hline F1296 & Standard Guide for Evaluating Chemical Protective Clothing \\
\hline F1301 & Standard Practice for Labeling Chemical Protective Clothing \\
\hline F1383 & $\begin{array}{l}\text { Standard Test Method for Permeation of Liquids and Gases through } \\
\text { Protective Clothing Materials under Conditions of Intermittent Contact }\end{array}$ \\
\hline F1407 & $\begin{array}{l}\text { Standard Test Method for Resistance of Chemical Protective Clothing } \\
\text { Materials to Liquid Permeation/Permeation Cup Method }\end{array}$ \\
\hline F1448 & $\begin{array}{l}\text { Standard Guide for Selection of Security Technology for Protection } \\
\text { Against Counterfeiting, Alteration, Diversion, Duplication, Simulation, and } \\
\text { Substitution (CADDSS) of Products or Documents }\end{array}$ \\
\hline F1461 & Standard Practice for Chemical Protective Clothing Program \\
\hline F1468 & $\begin{array}{l}\text { Standard Practice for Evaluation of Metallic Weapons Detectors for } \\
\text { Controlled Access Search and Screening }\end{array}$ \\
\hline F2053 & $\begin{array}{l}\text { Standard Guide for Documenting the Results of Airborne Particle } \\
\text { Penetration Testing of Protective Clothing Materials }\end{array}$ \\
\hline F2061 & $\begin{array}{l}\text { Standard Practice for Chemical Protective Clothing: Wearing, Care, and } \\
\text { Maintenance Instructions }\end{array}$ \\
\hline F2069 & Standard Practice for Evaluation of Explosives Vapor Detectors \\
\hline F2103 & $\begin{array}{l}\text { Standard Guide for Characterization and Testing of Chitosan Salts as } \\
\text { Starting Materials Intended for Use in Biomedical and Tissue-Engineered } \\
\text { Medical Product Applications }\end{array}$ \\
\hline F2401 & $\begin{array}{l}\text { Standard Practice for Security Checkpoint Metal Detector Screening of } \\
\text { Persons with Medical Devices }\end{array}$ \\
\hline F2588 & $\begin{array}{l}\text { Standard Test Method for Man-In-Simulant Test (MIST) for Protective } \\
\text { Ensembles }\end{array}$ \\
\hline NIJ-0101.04 & $\begin{array}{l}\text { NIJ Standard-0101.04 NIJ STANDARD FOR BALLISTIC RESISTANCE } \\
\text { OF PERSONAL BODY ARMOR }\end{array}$ \\
\hline NIJ-0101.04AddendumB & $\begin{array}{l}\text { NIJ STANDARD-0101.04 BALLISTIC RESISTANCE OF PERSONAL } \\
\text { BODY ARMOR ADDENDUM B }\end{array}$ \\
\hline NIJ-0101.04RevA & $\begin{array}{l}\text { NIJ Standard-0101.04 NIJ STANDARD FOR BALLISTIC RESISTANCE } \\
\text { OF PERSONAL BODY ARMOR }\end{array}$ \\
\hline NIJ-0106.01 & NIJ 0106.01 NIJ Standard for Ballistic Helmets \\
\hline NIJ-0108.01 & NIJ Standard 0108.01 Ballistic Resistant Protective Materials \\
\hline NIJ-0112.03 & $\begin{array}{l}\text { NIJ Standard-0112.03 NIJ STANDARD FOR AUTOLOADING PISTOLS } \\
\text { FOR POLICE OFFICERS }\end{array}$ \\
\hline NIJ-0115.00 & $\begin{array}{l}\text { NIJ Standard-0115.00 NIJ STANDARD FOR STAB RESISTANCE OF } \\
\text { PERSONAL BODY ARMOR }\end{array}$ \\
\hline NIJ-0204.02 & NIJ Standard-0204.02 NIJ STANDARD FOR FIXED AND BASE \\
\hline
\end{tabular}




\section{STATION ANTENNAS}

NIJ-0211.01

NIJ-0307.01

NIJ-0601.02

NIJ-0602.02

NIJ-0604.01

NIJ-TP-99-114

169587

177600

178261

178913-1

179545-3

181622

184432

186634

172868

179545

187736

188292

189724

190747
NIJ Standard-0211.01 NIJ STANDARD FOR RECHARGEABLE BATTERIES FOR PERSONAL/PORTABLE TRANSCEIVERS

\section{NIJ 0307 - NIJ STANDARD FOR METALLIC HANDCUFFS}

NIJ Standard?0601.02 NIJ STANDARD FOR WALK-THROUGH METAL DETECTORS FOR USE IN CONCEALED WEAPON AND CONTRABAND DETECTION

NIJ Standard-0602.02 NIJ STANDARD FOR HAND-HELD METAL DETECTORS FOR USE IN CONCEALED WEAPON AND CONTRABAND DETECTION

NIJ Standard-0604.01 NIJ STANDARD FOR COLOR TEST REAGENTS/KITS FOR PRELIMINARY IDENTIFICATION OF DRUGS OF ABUSE

NIJ TEST PROTOCOL 99-114 FOR COMPARATIVE EVALUATION OF PROTECTIVE GLOVES FOR LAW ENFORCEMENT AND CORRECTIONS APPLICATIONS

NIJ Guide 100-98 Selection and Application Guide to Police Body Armor

NIJ TEST PROTOCOL 99-114 Test Protocol For Comparative Evaluation Of Protective Gloves For Law Enforcement And Corrections Applications

NIJ Report 100-99 Evaluation of a Test Protocol for Explosives Trace Detectors Using a Representative Commercial Analyzer

NIJ Guide 100-99 Guide for the Selection of Commercial Explosives Detection Systems for Law Enforcement Applications

Video Surveillance Equipment Selection and Application Guide

NIJ GUIDE 500-00 Guide To Test Methods, Performance Requirements, And Installation Practices For Electronic Sirens Used On Law Enforcement Vehicles

NIJ Guide 602-00 Guide to the Technologies of Concealed Weapon and Contraband Imaging and Detection

NIJ Report 604-00 Flammable and Combustible Liquid Spill/Burn Patterns NIJ Guide 200-98 New Technology Batteries Guide

NIJ Guide 201-99 VIDEO SURVEILLANCE EQUIPMENT SELECTION AND APPLICATION GUIDE

Electronic Crime Scene Investigation A Guide for First Responders

Improved Analysis of DNA Short Tandem Repeats With Time-of-Flight Mass Spectrometry

NIJ Guide 103-00 Guide for the Selection of Chemical and Biological Decontamination Equipment for Emergency First Responders Volume I October 2001

NIJ Guide 101-00 An Introduction to Biological Agent Detection Equipment for Emergency First Responders 
191160

191161

191518

191519

191520

191521

168961

178913-2

181584

181169

199408

199758

213030

216041

217397

219603

197065

NIJ Guide 104-00 Guide for the Selection of Communication Equipment for Emergency First Responders Volume I February 2002

NIJ Guide 104-00 Law Enforcement and Corrections Standards and Testing Program Guide for the Selection of Communication Equipment for Emergency First Responders Volume II February 2002

NIJ Guide 102-00 Law Enforcement and Corrections Standards and Testing Program Guide for the Selection of Personal Protective Equipment for Emergency First Responders Volume I November 2002

NIJ Guide 102-00 Law Enforcement and Corrections Standards and Testing Program Guide for the Selection of Personal Protective Equipment for Emergency First Responders (Respiratory Protection) Volume IIa November 2002

NIJ Guide 102-00 Law Enforcement and Corrections Standards and Testing Program Guide for the Selection of Personal Protective Equipment for Emergency First Responders (Percutaneous Protection Garments) Volume IIb November 2002

NIJ Guide 102-00 Law Enforcement and Corrections Standards and Testing Program Guide for the Selection of Personal Protective Equipment for Emergency First Responders (Percutaneous Protection Apparel) Volume IIc November 2002

NIJ Research State and Local Law Enforcement Wireless Communications and Interoperability: A Quantitative Analysis

NIJ Guide 100-99 Guide for the Selection of Commercial Explosives Detection Systems for Law Enforcement Applications

Fire and Arson Scene Evidence: A Guide for Public Safety Personnel

A GUIDE for Explosion and Bombing SCENE INVESTIGATION

NIJ Forensic Examination of Digital Evidence: A Guide for Law Enforcement

NIJ Special Report Mass Fatality Incidents: A Guide for Human Forensic Identification

NIJ Special Report Investigative Uses of Technology: Devices, Tools, and Techniques

NIJ Research for Practice Pretrial Innovations for Domestic Violence Offenders and Victims

NIJ Research in Brief Adolescents, Neighborhoods, and Violence: Recent Findings From the Project on Human Development in Chicago Neighborhoods

NIJ Journal Issue NO. 258

NIJ Special REPORT Crisis Information Management Software (CIMS) Feature Comparison Report

SimplifiedICSforTransPro Simplified Guide to the Incident Command System for TRANSPORTATION PROFESSIONALS 


\begin{tabular}{|c|c|}
\hline 183260 & $\begin{array}{l}\text { NIJ Guide 601-00 Guide For The Selection Of Drug Detectors For Law } \\
\text { Enforcement Applications }\end{array}$ \\
\hline 184433 & $\begin{array}{l}\text { NIJ Guide 600-00 Users' Guide for Hand-Held and Walk-Through Metal } \\
\text { Detectors }\end{array}$ \\
\hline 184449 & $\begin{array}{l}\text { NIJ Guide 100-00 Guide for the Selection of Chemical Agent and Toxic } \\
\text { Industrial Material Detection Equipment for Emergency First Responders } \\
\text { Volume I }\end{array}$ \\
\hline 185030 & $\begin{array}{l}\text { NIJ Guide 202-00 Law Enforcement and Corrections Standards and Testing } \\
\text { Program Antenna System Guide }\end{array}$ \\
\hline E1968 & $\begin{array}{l}\text { Standard Guide for Microcrystal Testing in the Forensic Analysis of } \\
\text { Cocaine }\end{array}$ \\
\hline E2125 & $\begin{array}{l}\text { ASTM E 2125-07 Standard Guide for Microcrystal Testing in the Forensic } \\
\text { Analysis of Phencyclidine and Its Analogues }\end{array}$ \\
\hline F0739 & $\begin{array}{l}\text { ASTM F 0739-07 Standard Test Method for Permeation of Liquids and } \\
\text { Gases through Protective Clothing Materials under Conditions of } \\
\text { Continuous Contact }\end{array}$ \\
\hline F1359 & $\begin{array}{l}\text { ASTM F 1359-99a (Reapproved 2004) Standard Test Method for Liquid } \\
\text { Penetration Resistance of Protective Clothing or Protective Ensembles } \\
\text { Under a Shower Spray While on a Mannequin }\end{array}$ \\
\hline sharat-proc & An Identity Authentication System Using Fingerprints \\
\hline 168106 & $\begin{array}{l}\text { Forensic Laboratories: Handbook for Facility Planning, Design, } \\
\text { Construction, and Moving }\end{array}$ \\
\hline cobra_v3 & Chemical Biological Response Aide (v3.0.1) Users? Guide \\
\hline cobra_v11 & Pocket CoBRA (v1.1) Users? Guide \\
\hline de_courtroom & $\begin{array}{l}\text { Digital Evidence in the Courtroom: A Guide for Preparing Digital Evidence } \\
\text { for Courtroom Presentation }\end{array}$ \\
\hline electCSI & $\begin{array}{l}\text { NIJ Guide Electronic Crime Scene Investigation: A Guide for First } \\
\text { Responders }\end{array}$ \\
\hline radioComm & $\begin{array}{l}\text { Guide to Radio Communications Interoperability Strategies and Products } \\
\text { Report No. TE-02-02 }\end{array}$ \\
\hline 186276 & $\begin{array}{l}\text { NIJ Research Report Electronic Crime Needs Assessment for State and } \\
\text { Local Law Enforcement }\end{array}$ \\
\hline 212957 & $\begin{array}{l}\text { NIJ Special Report Test Results for Hardware Write Block Device: Digital } \\
\text { Intelligence FireFly } 800 \text { IDE (FireWire Interface) }\end{array}$ \\
\hline 212961 & $\begin{array}{l}\text { NIJ Special Report Test Results for Hardware Write Block Device: Digital } \\
\text { Intelligence UltraBlock SATA (USB Interface) }\end{array}$ \\
\hline 189633 & $\begin{array}{l}\text { NIJ Guide 100-01 Selection and Application Guide to Personal Body } \\
\text { Armor }\end{array}$ \\
\hline 178913 & $\begin{array}{l}\text { NCJ } 178913 \text { NIJ Guide 100-99 Guide for the Selection of Commercial } \\
\text { Explosives Detection Systems for Law Enforcement Applications }\end{array}$ \\
\hline 189725 & NCJ 189725 Guide for the Selection of Chemical and Biological \\
\hline
\end{tabular}




\begin{tabular}{|c|c|}
\hline & $\begin{array}{l}\text { Decontamination Equipment for Emergency First Responders NIJ Guide } \\
103 ? 00 \text { Volume II }\end{array}$ \\
\hline NIJ601-98 & $\begin{array}{l}\text { NIJ Report 601-98 Evaluation Of Analytical Methodologies For Non- } \\
\text { Intrusive Drug Testing: Supercritical Fluid Extraction Of Cocaine From } \\
\text { Hair }\end{array}$ \\
\hline NISTIR6418 & NISTIR 6418 User’s Manual for Lidar Target Simulator \\
\hline NISTIR6468 & $\begin{array}{l}\text { NISTIR } 6468 \text { Interlaboratory Studies on the Analysis of Hair for Drugs of } \\
\text { Abuse }\end{array}$ \\
\hline NISTIR6518 & NISTIR 65181999 Survey of Forensic Reference Materials \\
\hline NISTIR6825 & $\begin{array}{l}\text { NISTIR } 6825 \text { An Evaluation of Innovative Sweat-Based Drug Testing } \\
\text { Techniques for Use in Criminal Justice Drug Testing }\end{array}$ \\
\hline NISTIR6915 & $\begin{array}{l}\text { NISTIR } 6915 \text { Standards for Hand-Held and Walk-Through Metal Detectors } \\
\text { Used in Concealed Weapon and Contraband Detection }\end{array}$ \\
\hline
\end{tabular}




\section{Appendix B}

\section{Detailed Incident Management Component Criteria Search Terms}





\section{Appendix B}

\section{Detailed Incident Management Component Criteria Search Terms}

\section{Component I - Preparedness}

- Emergency $^{\dagger}$ Operations ${ }^{t}$ Center $^{(\infty r)}$ EOC

- Emergency $^{+}$response $^{+}$nongovernmental ${ }^{+}$organization $^{(\omega r)} \mathrm{NGO}$

$0{ }^{+}$private ${ }^{+}$outreach

- Emergency ${ }^{\dagger}$ management

o public $^{\dagger}$ awareness

0 information $^{\dagger}$ systems

- Emergency response

0 information ${ }^{+}$operations ${ }^{+}$security

o resource management

\section{I-A. Preparedness Organizations and Programs}

- $\quad$ Emergency ${ }^{\dagger}$ Preparedness

o ${ }^{+}$cycle

o + + planning

$0{ }^{+}$training

0 +equipping

o +exercising

$0 \quad+$ evaluating

$0 \quad{ }^{+}$corrective actions

$0{ }^{+}$mitigation actions

- Disaster $^{(0 r)}$ Emergency $^{\natural}$ Management

o Authority ${ }^{+}$Having $^{+}$Jurisdiction $^{(0 r)}$ AHJ

o Business $^{\star}$ Continuity ${ }^{\ddagger}$ Program

o Program

- Training

- Exercises $^{\dagger}$ Evaluations $^{t}$ Corrective $^{+}$Actions

- Public $^{\dagger}$ Communications ${ }^{\dagger}$ Planning

- Public ${ }^{+}$awareness

- Financial ${ }^{\dagger}$ Planning

- Resource $^{+}$Management

0 tPlanning

$0 \quad{ }^{+}$Objectives

- Mutual $^{+}$aid

0 tPlanning

o "Exercise

- Emergency ${ }^{\dagger}$ Operations

0 tPlanning

o ${ }^{+}$Control

- Financial Planning 


\section{I-B. Implement Emergency Preparedness Cycle}

- Emergency $^{+}$Operations ${ }^{+}$Plan $^{(0 x)}$ EOP

$0{ }^{+}$organization $^{+}$structures

o ${ }^{+}$roles ${ }^{+}$responsibilities

$0{ }^{+}$policies

o ${ }^{+}$protocols

$0{ }^{+}$concept $^{+}$of $^{+}$operations

$0{ }^{+}$hazard ${ }^{+}$specific ${ }^{+}$planning

o tresponse ${ }^{+}$procedures

$0{ }^{+}$action $^{+}$oriented $^{+}$checklists

o ${ }^{+}$Standard ${ }^{+}$Operating ${ }^{+}$Procedures

$0{ }^{+} \mathrm{SOP}$

o ${ }^{+}{ }^{+}$Field $^{+}$Operations ${ }^{+}$Guide

$0{ }^{+}$FOG

o ${ }^{+}$risk ${ }^{+}$based $^{+}$hazard

o ${ }^{+}$personnel ${ }^{+}$equipment

$0{ }^{+}$training ${ }^{+}$exercising

$0{ }^{+}$corrective $^{+}$action ${ }^{(0 r)}$ mitigation ${ }^{+}$plans

- ${ }^{+}$lessons ${ }^{+}$learned

- ${ }^{+}$reduce ${ }^{+}$risks

$0{ }^{+}{ }^{2}$ ecovery ${ }^{+}$plans

- ${ }^{+}$long-term

- ${ }^{+}$restoration

- Emergency $^{+}$response $^{+}$training ${ }^{+}$exercises

$0{ }^{+}$incident $^{+}$command

$0{ }^{+}$incident $^{+}$management

$0{ }^{+}$all ${ }^{+}$hazards

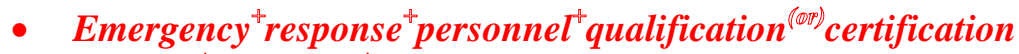

$0{ }^{+}$personnel $^{+}$qualification

o ${ }^{+}$personnel ${ }^{+}$credentialling

o ${ }^{+}$personnel ${ }^{+}$certification

- Emergency $^{+}$response $^{+}$equipment ${ }^{+}$certification

$0{ }^{+}$equipment ${ }^{+}$acquisition

o ${ }^{+}$performance

0 +interoperability

- Emergency $^{+}$response $^{+}$mutual $^{+ \text {aid }}{ }^{+}$agreements
o ${ }^{+}{ }^{\text {key }}{ }^{+}$terms
$0{ }^{+}{ }^{+}$oles ${ }^{+}$responsibilities
$0{ }^{+}$procedures
$0{ }^{+}$requesting ${ }^{+}$assistance
o ${ }^{+}$providing ${ }^{+}$assistance
$0{ }^{+}$reimbursement
0 +notification
$0{ }^{+}$interoperable ${ }^{+}$communications ${ }^{+}$protocols
$0{ }^{+}$relationships
$0{ }^{+}$other $^{+}$agreements
o ${ }^{+}{ }^{+}$workers ${ }^{+}$compensation
o ${ }^{+}$liability ${ }^{+}$immunity
$0{ }^{+}$recognition ${ }^{+}$fo $^{+}$qualifications
$0{ }^{+}$recognition ${ }^{+}$of $^{+}$certifications 
$0 \quad{ }^{+}$sharing ${ }^{+}$agreements

o ${ }^{+}$authorized $^{+}$officials $^{+}$approval

o ${ }^{+}$Local

o ${ }^{+}$Regional

0 +State

o ${ }^{+}$Federal

- Business $^{+}$Continuity ${ }^{+}$Programs

$0{ }^{+}$Recovery

$0{ }^{+}$Analysis

- $\quad$ Preparedness ${ }^{+}$hazard $^{+}$assessment

- Preparedness ${ }^{+}$risk $^{+}$assessment

- Hazard $^{+}$mitigation ${ }^{+}$strategy

- Risk $^{+}$Management

- Hazard ${ }^{+}$Assessment

- Hazard $^{+}$Mitigation

\section{Component II - Communications and Information management}

II-A. Communications and Incident Management

- Incident ${ }^{t}$ communications ${ }^{t}$ plan

- ICP

- Incident-based ${ }^{+}$communications ${ }^{+}$center

- Incident $^{+}$Command $^{+}$System ${ }^{(\oplus r)}$ ICS

o common terminology

o communications ${ }^{t}$ management

0 Intelligence ${ }^{t}$ sharing

- Communication procedures

- Communication Systems

- Incident Management System

- Mutual Aid Agreement

- Direction Control Coordination

- Crisis Communication

- Crisis Public Information

- Public awareness

II-B. Effective Communications, Information Management and Information Sharing

- Incident communications

O Incident $^{+}$Command $^{+}$common $^{+}$communications $^{+}$operating $^{+}$system

o Incident $^{+}$Command $^{+}$interoperabile ${ }^{+}$communications

- Emergency

o Communications

o Warnings

- Public Communications

- Communication Warnings 


\section{II-C. Establishing and Maintaining a Common Operating Picture and Ensuring Accessibility and Interoperability}

- Common $^{+}$incident ${ }^{+}$management ${ }^{+}$operating ${ }^{+}$picture

$0 \quad{ }^{+}$accessibility

$0{ }^{+}$interoperability

II-D. Managing Interoperable Communications and Data

- Managing incident communication

- Managing ${ }^{+}$incident $^{+}$data

- Incident ${ }^{+}$information ${ }^{+}$management $t^{+}$policies

- Emergency $^{+}$Operations ${ }^{+}$Center $^{(0 r)}$ EOC

o networks

- Incident $^{t}$ Action $^{+P^{+}}$Plan $^{(0)}$ IAP

$0{ }^{+}{ }^{+}$indications ${ }^{+}$warnings

$0{ }^{+}{ }^{+}$incident ${ }^{+}$notifications

o ${ }^{+}$public ${ }^{+}$communications

o ${ }^{+}$technology ${ }^{+}$use

$0{ }^{+}$information ${ }^{+}$management

$0{ }^{+}{ }^{+}$integrate $^{+}$command $^{+}$tactical $^{+}$support ${ }^{+}$units

$0{ }^{+}$incident $^{+}$situation $^{+}$report

- Incident Communications Plan ${ }^{(0 r)}$ ICP

\section{Component III - Resource Management}

III-A. Categorizing Resources

- Emergency ${ }^{+}$response ${ }^{+}$credentialing

- Emergency ${ }^{+}$response ${ }^{+}$resource ${ }^{+}$typing

o ${ }^{+}$Size

o ${ }^{+}$Capacity

o ${ }^{+}$Skill

III-B. Effective Management of Resources

- Emergency $^{+}$response $e^{+}$resource ${ }^{t}$ acquisition

- Emergency ${ }^{+}$response $e^{+}$resource ${ }^{+}$allocation

- Emergency response $e^{+}$resource ${ }^{+}$tracking

- Iinventorying emergency response resources

o Supplies

o Equipment

o Facilities

o Personnel

o Response personnel

o Response teams

- Resource Management

- Resource planning

- Resource objectives

- Mutual aid planning

- Mutual aid agreements 


\section{III-C. Inventorying Process}

- Local $^{+}$EOC $^{+}$resource ${ }^{+}$inventorying

- Local I Emergency $^{+}$Operations $^{+}$Center $^{+}$resource ${ }^{+}$inventorying

- Multiagency pre-incidednt resource ${ }^{+t}$ inventorying

- Multiagency ${ }^{+}$incident $t^{+}$response ${ }^{+}$resource ${ }^{+}$inventorying

- Validated incident $t^{+}$resources ${ }^{+}$inventorying

0 tacquisition

$0{ }^{+}$management ${ }^{+}$information

0 +ordering

$0{ }^{+}$mobilization

$0 \quad+$ dispatching

o ${ }^{+}$demobilization

0 tbudgeting

o replenishment

o ${ }^{+}$preventive ${ }^{+}$maintenance

$0{ }^{+}{ }^{+}$capital ${ }^{+}$improvements

$0 \quad{ }^{+}$warehousing

\section{III-D. Resource Acquisition}

- Identifying ${ }^{+}$emergency response $e^{+}$resource requirements

- Ordering ${ }^{+}$emergency ${ }^{+}$response $e^{+}$resources

- Acquiring emergency response ${ }^{\dagger}$ resources

- Mutual Aid Agreement

- Mutual Aid Planning

\section{IIIE. Mobilizing Resources}

- Emergency $^{+}$response $e^{+}$resource $e^{+t} d a t e^{+t}$ time $^{+}$place $^{+}$of $f^{+}$departure

- Emergency ${ }^{+}$response $e^{+}$resource ${ }^{+}$mode $e^{+}$of $^{+}$transportation

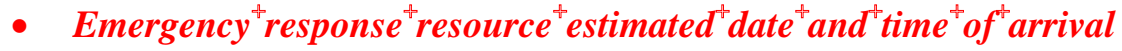

- Emergency ${ }^{+}$response $^{+}$resource ${ }^{t}$ reporting ${ }^{+1}$ location

- Emergency $^{+}$response $^{+}$resource ${ }^{+}$anticipated ${ }^{+}$assignment $^{+}$

- Emergency ${ }^{\dagger}$ response $e^{\dagger}$ resource $e^{+}$order ${ }^{+}$number

- Emergency $^{+}$response $e^{+}$resource ${ }^{+}$incident $t^{+}$number

- Emergency $^{+}$response $^{+}$resource ${ }^{+}$cost $^{+}$funding $^{+}$codes

\section{III-F. Recovering Resources}

- Emergency response $^{\dagger}$ resource ${ }^{+t}$ demobilization

0 personnel

- +occupational ${ }^{+}$health

- ${ }^{+}$mental ${ }^{+}$health

- ${ }^{+}$monitoring

$0{ }^{+}$nonexpendable ${ }^{+}$resources

- trestore

- ${ }^{+}$replace

$0{ }^{+}$expendable ${ }^{+}$resources

- taccounting

- ${ }^{+}$restocking 
III-G. Reimbursement

- Emergency $^{+}$response $^{+}$resource ${ }^{+}$reimbursement $t^{+}$process

$0{ }^{+}{ }_{\text {life }}^{+}{ }^{+}$cycle ${ }^{+}$costing

$0{ }^{+}$incident ${ }^{+}$life ${ }^{+}$cycle

$0{ }^{+}$life ${ }^{+}$cycle

o tbilling

o collecting

- Finance

- Financial Administration

\section{Component IV - Command and Management}

\section{IV-A. Field Command and Management Functions}

- Incident Command $^{\dagger}$ System $^{(0 p)}$ ICS $^{\dagger}$ organization

0 * doctrine

0 tprocedures

- Flexible $^{+}$ICS $^{+}$organization $^{+}$structure $^{+}$

O Incident ${ }^{+}$Commander $^{+}$authority

$0 \quad{ }^{+}$hazard-based ${ }^{+}$flexibility

- Emergency Operations

- Emergency Control Planning

- Program Management

- Advisory Committee

- Tactical Operations

- Emergency Operations Center ${ }^{(0 r)}$ EOC

IV-B. Modular, Scalable Incident Command System

- Incident $^{+t}$ Command $^{+}$System ${ }^{(\infty r)}$ ICS

$0{ }^{\star}$ single $^{\star}$ jurisdiction ${ }^{(\oplus r)}$ agency

$0{ }^{+}$multiple ${ }^{+}$jurisdictions ${ }^{(\oplus r)}$ agencies

$0 \quad{ }^{+}$applicable ${ }^{+}$throughout ${ }^{+}$country

o ${ }^{+}$adaptable ${ }^{+}$new $^{+}$technology

$0{ }^{+}$adaptable ${ }^{+}$incidents

$0{ }^{+}$scalable $^{+}$organization ${ }^{+}$structure

IV-C. Interactive Management Components

- Incident Command $^{+}$System $^{(0 r)}$ ICS

0 implemented $^{+}$processes $^{+}$procedures $^{+t}$ plans

\section{IV-D. Measurable objectives}

- Incident management ${ }^{\dagger}$ goals

- Incident ${ }^{+}$management ${ }^{+}$objectives

\section{IV-E. Management Characteristics}

- Incident ${ }^{+}$management ${ }^{+}$terminology

$0{ }^{+}$organizational ${ }^{+}$function

o resource ${ }^{\dagger}$ descriptions

$0{ }^{+}$capability ${ }^{\dagger}$ based $^{+}$resource ${ }^{+}$typing

0 incident facility 
IV-F. Modular Organization

- Top $^{+}$down $^{+}$incident ${ }^{+}$management ${ }^{+}$organization $^{+}$structure

- Incident management $t^{+}$command $^{+}$structure $^{+}$based $^{+}$on $^{+}$incident $^{+}$complexity

- Incident ${ }^{+t}$ Commander $r^{+t}$ determines ${ }^{+t}$ ICS $^{+}$expansion

- Number $^{+}$of $^{+}$Incident $^{+}$Command $^{+}$positions ${ }^{+}$expands $^{+}$with $^{+}$incident $^{+}$expansion

- Incident $^{+t}$ Command $^{+}$System $^{(0 t)}$ ICS $^{\dagger}$ hazard $^{+t}$ specific $^{\dagger}$ expansion

- Logistics

- Facilities

IV-G. Management by Objectives

- Overarching incident management ${ }^{+}$objectives

- Specific ${ }^{+}$measurable ${ }^{+}$incident $t^{+}$management objectives

$0{ }^{+}$functions

$0{ }^{+}$activities

- Documentating ${ }^{\dagger}$ incident $^{\dagger}$ management ${ }^{\dagger}$ activities

- Incident management ${ }^{+}$corrective $^{+t}$ action $^{+t}$ plan

IV-H. Incident Action Plan

- Incident action plan

- IAP

- Accountability

- Emergency management Control

- Span of control

- Command general staffing

- Incident command functions

- Multi-agency coordination

IV-I. Manageable Span of Control

- Incident $^{+}$Command $^{+}$System ${ }^{(0 x)}$ ICS

$0{ }^{\dagger}$ supervisory ${ }^{(0 r)}$ span $^{\dagger}$ of control

O ${ }^{+}$supervisor ${ }^{+}$span $^{+}$three $^{+}$to $^{+}$seven $^{+}$subordinates

- ISO Responsibilities

- Incident safety officer

\section{IV-J. Predesignated Incident Locations and Facilities}

- Incident ${ }^{+t}$ Command determines ${ }^{\dagger}$ operational $^{\dagger}$ locations

- Incident management $t^{+}$facilities ${ }^{+t}$ situationally ${ }^{+}$located

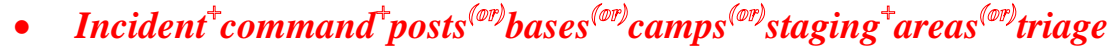

\section{IV-K. Comprehensive Resource Management}

- Incident management $t^{t}$ resource $e^{t} u t_{i l i z a t i o n}$

- Incident ${ }^{+}$management ${ }^{+}$resource ${ }^{+}$categorizing

- Incident ${ }^{+}$management $t^{\dagger}$ resource $e^{+}$ordering

- Incident management $t^{\dagger}$ resource dispatching

- Incident ${ }^{+}$management ${ }^{+}$resource $e^{+}$tracking

- Incident management $t^{\dagger}$ resource ${ }^{t}$ recovering

- Incident management ${ }^{\dagger}$ reimbursement

- Domestic ${ }^{+}$incident ${ }^{+}$management 


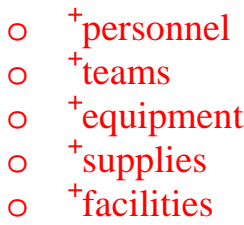

- Incident resource management

- Mutual Aid

\section{IV-L. Integrated Communications}

- Incident ${ }^{+}$management ${ }^{+}$common $^{+}$communications $^{+}$plan

- Incident $t^{+}$management ${ }^{+}$interoperable ${ }^{+}$communications

$0{ }^{+}$processes

- Incident $t^{+}$management ${ }^{+}$interoperable $^{+}$communications $^{+}$architecture

$0{ }^{+}{ }^{\text {common }}{ }^{+}$communications

- +equipment

- + ${ }^{\text {systems }}$

- "tprotocols

o ${ }^{+}$integrated $^{+}$voice ${ }^{+}$data $^{+}{ }^{+}$communications ${ }^{+}$systems

IV-M. Establishment and Transfer of Command

- Incident ${ }^{t}$ command ${ }^{+}$establishment

- Incident command primary ${ }^{+t}$ authority ${ }^{\dagger}$ establishment

- Incident command transfer

- Incident $t^{+}$command $^{+}$transfer $^{+}$briefing

IV-N. Unified Command

- Institutionalized ${ }^{+}$incident $^{\dagger}$ unified $^{+}$command ${ }^{\dagger}$ process

- Unified ${ }^{+}$command $^{+}$single ${ }^{+}$jurisdiction $^{+}$with $^{+}$multiagency ${ }^{+}$involvement

- Unified $^{+}$command $^{+}$agency ${ }^{+}$authority

- Unified $d^{+}$command $d^{+}$agency $y^{+t}$ responsibility

- Unified ${ }^{+}$command $^{+}$agency $^{+}$accountability $^{-}$

- Interagency coordination

\section{IV-O. Incident Management Accountability}

- Incident ${ }^{t}$ check-in procedures

$0{ }^{+}{ }^{+}$esponders ${ }^{+}$assigned ${ }^{+}{ }^{+} e^{+}$supervisor

$0{ }^{+}{ }^{+}$responders ${ }^{+}$report-in ${ }^{+}$procedures

$0{ }^{+}$response $^{+}$operations ${ }^{+}$direction $^{+}$and $^{+}$control

o ${ }^{+}{ }^{+}$resource ${ }^{+}$status $^{+}$changes $^{+}$recording ${ }^{+}$reporting

- Incident ${ }^{+t}$ Action ${ }^{+}$Plan

- IAP

- Incident $^{+}$Unity $^{+}$of $^{+}$Command

- Incident Command ${ }^{\dagger}$ Span $^{\dagger}$ of Control

- Incident ${ }^{+}$Resource $e^{+}$Tracking

\section{IV-P. Incident Management Deployment}

- Emergency $^{+}$response ${ }^{+}$personnel ${ }^{+}$on $^{+}$request $^{+}$dispatch

- Emergency $^{\dagger}$ response $e^{+}$equipment $t^{\dagger}{ }^{+}{ }^{+}$request $^{+}$dispatch $^{-}$

- Emergency ${ }^{\dagger}$ responder ${ }^{\dagger}$ self-dispatch 
IV-Q. Information and Intelligence Management

- Emergency $^{+}$management ${ }^{+}$jurisdiction

$\begin{array}{ll}\text { o } & { }^{+} \text {information }{ }^{+} \text {gathering } \\ 0 & { }^{+} \text {information } \\ \text { o sharing } \\ \text { o } & { }^{+} \text {intelligence }{ }^{+} \text {sharing }\end{array}$

IV-R. ICS Organization and Operations

- Incident ${ }^{+}$Command $^{+}$System ${ }^{(0 r)}$ ICS

$0{ }^{+}$organization ${ }^{t}$ operations

$0 \quad{ }^{+}$command $^{+}$general ${ }^{+}$staff

$0{ }^{+}{ }^{+}$command $^{+}$staff ${ }^{+}$responsibilities

o ${ }^{+}$Public ${ }^{+}$Information ${ }^{+}$Officer

$0 \quad{ }^{+} \mathrm{PIO}$

$0 \quad{ }^{\dagger}$ Safety Officer

$0{ }^{+} \mathrm{SO}$

O ${ }^{\dagger}$ Liaison $^{\dagger}$ Officer

O ${ }^{\dagger}$ LNO

o ${ }^{+}$Operations ${ }^{\dagger}$ Section ${ }^{\dagger}$ Chief

$0{ }^{+}$Planning ${ }^{+}$Section ${ }^{\dagger}$ Chief

O $\quad{ }^{+}$Logistics $^{\dagger}$ Planning ${ }^{\dagger}$ Chief

$0 \quad{ }^{*}$ Finance/Administration ${ }^{+}$Chief

$0{ }^{+}$Advisory ${ }^{\dagger}$ Committee $^{\star t}$ interagency ${ }^{+}$coordination

o + Business ${ }^{+}$continuity

- Public Information Officer PIO

- Safety Officer SO

- Liason Officer LNO

- Operations Section chief

- Logistics Planning chief

- Finance chief

- Finance/Administration $^{+}$Chief

- Advisory committee

- Business Continuity

\section{IV-S. ICS Single Command IC}

- Single Incident+Command ${ }^{(0 r)} \mathrm{IC}^{+{ }^{+}}$single jurisdiction ${ }^{+}$incident

- Single $^{\dagger}$ Incident ${ }^{+}$Command $^{(0 r)}$ IC $^{+}$multiple ${ }^{+}$jurisdiction $^{+}$incident

- Incident ${ }^{+}$Command $^{(0)}$ IC $^{+}$Incident $^{+}$Action ${ }^{+}$Plan

- Incident ${ }^{+t}$ Command ${ }^{(\varpi)}$ IC $^{+}$incident $^{+}$objectives

IV-T. ICS Unified Command UC

- Unified Command ${ }^{(0 r)} U C^{+}$structure

- Unified ${ }^{+}$Command ${ }^{(0)} U^{+} C^{\dagger}$ incident $t^{\dagger}$ strategies

- Unified ${ }^{+}$Command ${ }^{(\varpi)} U C^{+}$objectives

- Unified $^{+}$Command $^{(\oplus r)} \mathrm{UC}^{+}$joint $^{+}$tactical $^{+}$operations

- Establishment of command

- Transfer of command

- Termination of command 
IV-U. ICS Incident Action Plan (IAP)

- Planning $^{+}$Section $^{+}$Chief $^{+}$IAP $^{(0 t)}$ Incident $^{+}$Action ${ }^{+}$Plan

- Incident $^{+}$Action+Plan ${ }^{(0 \pi)}$ IAP $^{+}$Unified $^{+}$Command $^{(0)}$ UC $^{+}$approval

- Operations $^{\dagger}$ Section $^{+}$Chief $^{\dagger}$ Incident $^{+}$Action $^{\dagger}$ Plan $^{(0 r)}$ IAP $^{+}$implementation

IV-V. ICS Resources

- Incident ${ }^{+}$Command $^{+}$System ${ }^{(\oplus r)}$ ICS

$0{ }^{\dagger}$ Single Resources

o ${ }^{\ddagger}$ Task ${ }^{\dagger}$ Forces

$0 \quad{ }^{+}$Strike ${ }^{\text {th }}$ Teams

IV-W. ICS Area Command

- Area $^{+}$Command $^{+}$Multiple $^{+}$incidents

- Area $^{\dagger}$ Command Large ${ }^{\dagger}$ incident

- Unified ${ }^{+}$Area $^{+}$Command

IV-X. Emergency Operations Center

- Emergency $^{+}$Operations ${ }^{+}$Center

- EOC

- Emergency $^{+}$Operations ${ }^{+}$Center $^{(0 r)}$ EOC $^{-1}$

$0{ }^{\dagger}$ resource ${ }^{\ddagger}$ dispatch tracking

$0{ }^{*}$ multiagency ${ }^{+}$coordination ${ }^{+}$entities

IV-Y. Joint Information System (JIS) and Center (JIC)

- JIS

- Joint Information $^{+}$System

- JIC

- Joint Information ${ }^{+}$Center

IV-Z. Incident Management Hazard Identification, Risk Management, and Impact Analysis

- Incident Management

o Hazard Identification

o Risk Assessment

- Impact analysis

o Hazard Mitigation

- Program evaluation

- Business continuity

\section{Component V - Supporting Technologies}

- Incident $^{+C^{+}}$Command ${ }^{+}$System $^{(\bullet r)}$ ICS

$0 \quad{ }^{\star}$ Technology

o ${ }^{+}$voice $^{+}$data $^{+}$communications ${ }^{\dagger}$ systems

$0{ }^{\dagger}$ voice $^{\dagger}$ data $^{\dagger}$ display ${ }^{\dagger}$ systems

$0 \quad{ }^{\dagger}$ Emergency ${ }^{\dagger}$ Operations ${ }^{\dagger}$ Center $^{+}$Technology

Legend

${ }^{+}=>\quad$ means "and" for a linked word string that needs to be found in relationship together before tool will return a find.

$(\mathrm{or})=>$ means these terms are exchangeable and need to be search with the ${ }^{+}$terms using both terms is separate word relationship strings (e.g., Emergency ${ }^{+}$Operations ${ }^{+} \mathrm{Center}^{(\mathrm{Or})}$ EOC $^{+}$resource ${ }^{+}$dispatch $^{+}$tracking should be searched as

Emergency ${ }^{+}$Operations ${ }^{+}$Center $^{+}$resource ${ }^{+}$dispatch ${ }^{+}$tracking and as $\mathrm{EOC}^{+}$resource $^{+}$dispatch ${ }^{+}$tracking). 


\section{Appendix C}

\section{Color-Coded Law Enforcement Standards and Guides Dashboard Tables}





\section{Appendix C}

Color-Coded Law Enforcement Standards and Guides Dashboard Tables

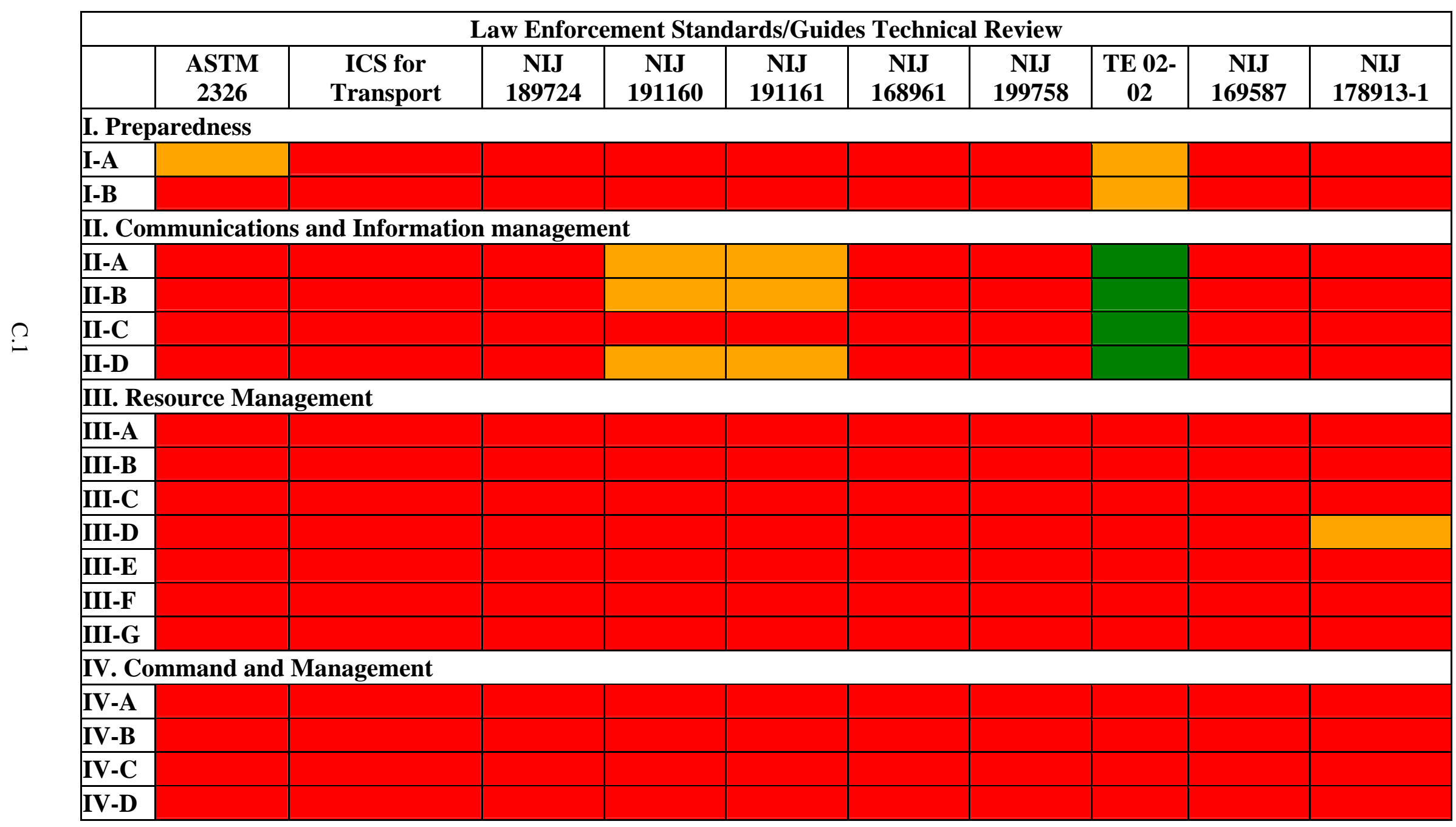




\begin{tabular}{|l|l|l|l|l|l|l|l|l|l|l|}
\hline \multicolumn{9}{|c|}{ Law Enforcement Standards/Guides Technical Review } \\
\hline
\end{tabular}




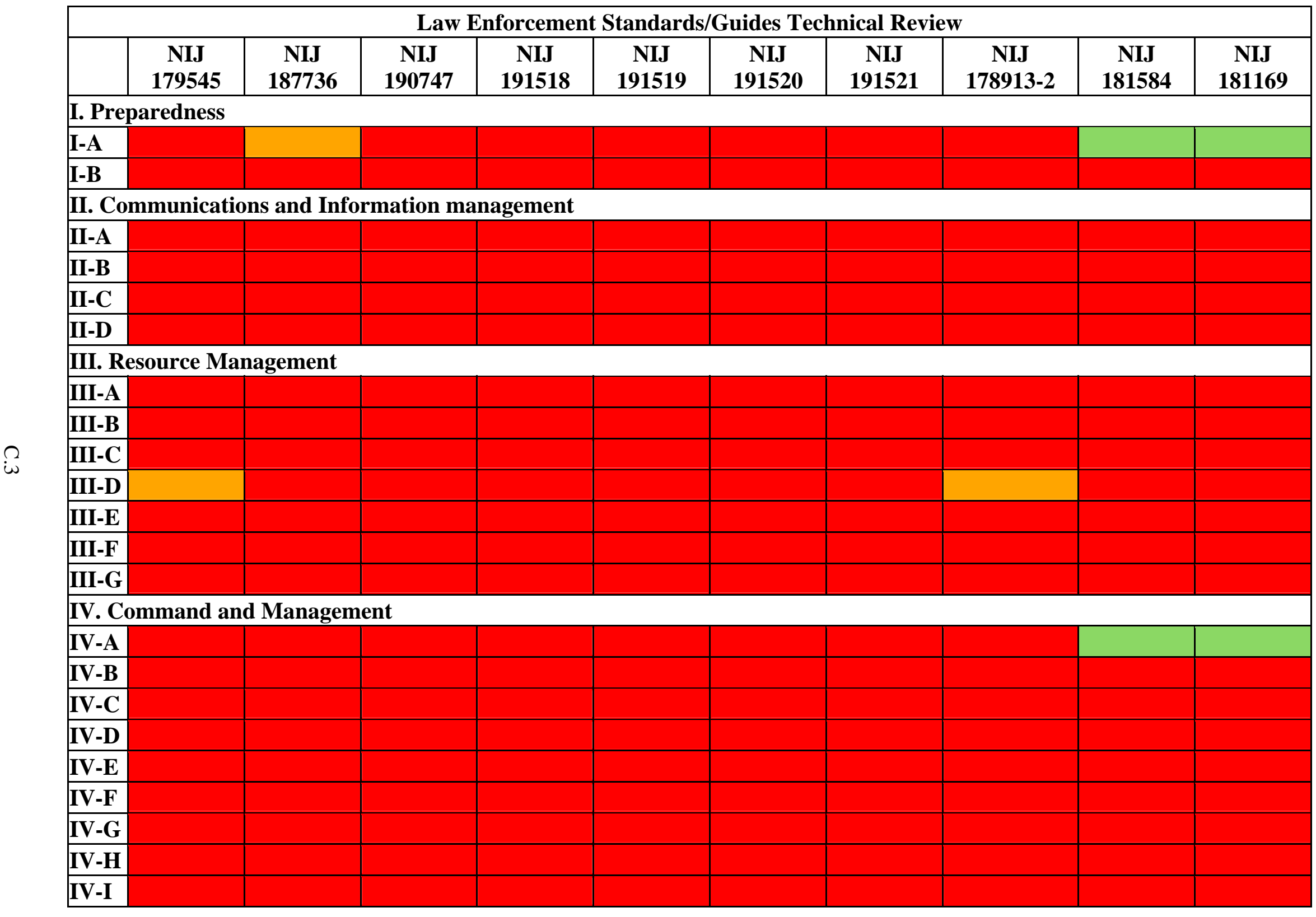




\begin{tabular}{|l|l|c|c|c|c|c|c|c|c|c|}
\hline \multicolumn{9}{|c|}{ Law Enforcement Standards/Guides Technical Review } \\
\hline
\end{tabular}




\begin{tabular}{|c|c|c|c|c|c|c|c|c|c|c|c|}
\hline \multicolumn{12}{|c|}{ Law Enforcement Standards/Guides Technical Review } \\
\hline & $\begin{array}{c}\text { NIJ } \\
199408\end{array}$ & $\begin{array}{l}\text { NIJ } \\
213030\end{array}$ & $\begin{array}{c}\text { NIJ } \\
182360\end{array}$ & $\begin{array}{c}\text { NIJ } \\
184433\end{array}$ & $\begin{array}{c}\text { NIJ } \\
184499\end{array}$ & ESCI & $\begin{array}{c}\text { NIJ } \\
189633\end{array}$ & $\begin{array}{c}\text { NIJ } \\
178913-1\end{array}$ & $\begin{array}{c}\text { NIJ } \\
189725\end{array}$ & $\begin{array}{l}\text { NISTIR } \\
6518\end{array}$ & $\begin{array}{c}\text { OSHA } \\
\text { 3335-10N }\end{array}$ \\
\hline \multicolumn{12}{|c|}{ I. Preparedness } \\
\hline \multicolumn{12}{|c|}{\begin{tabular}{|l|l|}
$\mathbf{I}-\mathbf{A}$ \\
\end{tabular}} \\
\hline I-B & & & & & & & & & & & \\
\hline \multicolumn{12}{|c|}{ II. Communications and Information management } \\
\hline \multicolumn{12}{|c|}{\begin{tabular}{|l|l|l|l|} 
II-A & & & \\
\end{tabular}} \\
\hline \multicolumn{12}{|l|}{ II-B } \\
\hline \multicolumn{12}{|l|}{ II-C } \\
\hline \multicolumn{12}{|l|}{ II-D } \\
\hline \multicolumn{12}{|c|}{ III. Resource Management } \\
\hline \multicolumn{12}{|l|}{ III-A } \\
\hline \multicolumn{12}{|l|}{ III-B } \\
\hline \multicolumn{12}{|l|}{ III-C } \\
\hline \multirow{2}{*}{\multicolumn{12}{|c|}{ III-D }} \\
\hline & & \multicolumn{10}{|c|}{ III-E } \\
\hline \multicolumn{12}{|l|}{ III-F } \\
\hline \multirow{2}{*}{\multicolumn{12}{|c|}{\begin{tabular}{|l|l|l|} 
III-G & \\
IV. Command and Management \\
\end{tabular}}} \\
\hline & & & & & & & & & & & \\
\hline \multicolumn{12}{|l|}{ IV-A } \\
\hline \multicolumn{12}{|l|}{ IV-B } \\
\hline \multicolumn{12}{|l|}{ IV-C } \\
\hline \multicolumn{12}{|l|}{ IV-D } \\
\hline \multicolumn{12}{|l|}{ IV-E } \\
\hline \multicolumn{12}{|l|}{ IV-F } \\
\hline \multirow{2}{*}{\multicolumn{12}{|c|}{\begin{tabular}{|l|} 
IV-G \\
IV-H \\
\end{tabular}}} \\
\hline & & & & & & & & & & & \\
\hline IV-I & & & & & & & & & & & \\
\hline
\end{tabular}




\begin{tabular}{|c|c|c|c|c|c|c|c|c|c|c|c|}
\hline \multicolumn{12}{|c|}{ Law Enforcement Standards/Guides Technical Review } \\
\hline & $\begin{array}{c}\text { NIJ } \\
199408\end{array}$ & $\begin{array}{c}\text { NIJ } \\
213030\end{array}$ & $\begin{array}{c}\text { NIJ } \\
182360\end{array}$ & $\begin{array}{c}\text { NIJ } \\
184433\end{array}$ & $\begin{array}{c}\text { NIJ } \\
184499\end{array}$ & ESCI & $\begin{array}{c}\text { NIJ } \\
189633\end{array}$ & $\begin{array}{c}\text { NIJ } \\
\text { 178913-1 }\end{array}$ & $\begin{array}{c}\text { NIJ } \\
189725\end{array}$ & $\begin{array}{c}\text { NISTIR } \\
6518\end{array}$ & $\begin{array}{c}\text { OSHA } \\
\text { 3335-10N }\end{array}$ \\
\hline \multicolumn{12}{|l|}{ IV-J } \\
\hline \multicolumn{12}{|l|}{ IV-K } \\
\hline \multicolumn{12}{|l|}{ IV-L } \\
\hline \multicolumn{12}{|c|}{ IV-M } \\
\hline \multicolumn{12}{|l|}{ IV-N } \\
\hline \multicolumn{12}{|l|}{ IV-O } \\
\hline \multicolumn{12}{|l|}{ IV-P } \\
\hline \multicolumn{12}{|l|}{ IV-Q } \\
\hline \multicolumn{12}{|l|}{ IV-R } \\
\hline \multicolumn{12}{|l|}{ IV-S } \\
\hline \multicolumn{12}{|l|}{ IV-T } \\
\hline \multicolumn{12}{|l|}{ IV-U } \\
\hline \multicolumn{12}{|l|}{ IV-V } \\
\hline \multicolumn{12}{|c|}{ IV-W } \\
\hline \multicolumn{12}{|l|}{ IV-X } \\
\hline \multicolumn{12}{|l|}{ IV-Y } \\
\hline IV-Z & & & & & & & & & & & \\
\hline V.Sul & $\operatorname{ting} T_{r}$ & ologies & & & & & & & & & \\
\hline
\end{tabular}




\section{Distribution}

No. of

Copies

Offsite

8 S\&T TSD STOP 0215

Department of Homeland Security 245 Murray LN

Washington DC 20528-0215

Bert Coursey (1 + PDF)

Phil Mattson (5 + PDF)

Tod Companion (1 + PDF)

Peter Shebell (1 + PDF)

3 Jennifer Marshall

Office of Law Enforcement Standards

National Institute of Standards and

Technology

Mail Stop 8102

100 Bureau Drive

Gaithersburg, MD 20899

(3 + PDF)

1 SL Stein

BSRC

1100 Dexter Ave N. Suite 400

Seatttle, WA 98109
No. of

Copies

\section{Onsite}

Pacific Northwest National Laboratory

$\begin{array}{ll}\text { BL Hoops } & \text { K6-52 } \\ \text { AM Lesperance } & \text { BSRC } \\ \text { SW Martin } & \text { K8-21 } \\ \text { MM Mitchell } & \text { K8-29 } \\ \text { RD Stenner + PDF } & \text { K3-54 }\end{array}$






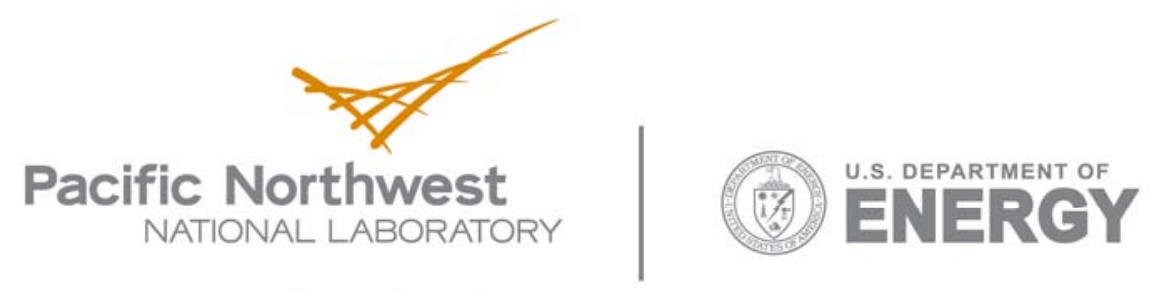

902 Battelle Boulevard

P.O. Box 999

Richland, WA 99352

1-888-375-PNNL (7665)

www.pnl.gov 